\title{
National Register of Historic Places (NRHP) Eligibility Testing of 41BX1749, Bexar County, Texas
}

Antonia L. Figueroa

Center for Archeological Research, University of Texas at San Antonio

Follow this and additional works at: https://scholarworks.sfasu.edu/ita

Part of the American Material Culture Commons, Archaeological Anthropology Commons, Environmental Studies Commons, Other American Studies Commons, Other Arts and Humanities Commons, Other History of Art, Architecture, and Archaeology Commons, and the United States History Commons

Tell us how this article helped you.

This Article is brought to you for free and open access by the Center for Regional Heritage Research at SFA ScholarWorks. It has been accepted for inclusion in Index of Texas Archaeology: Open Access Gray Literature from the Lone Star State by an authorized editor of SFA ScholarWorks. For more information, please contact cdsscholarworks@sfasu.edu. 


\section{National Register of Historic Places (NRHP) Eligibility Testing of 41BX1749, Bexar County, Texas}

\section{Licensing Statement}

This is a work produced for the Texas Department of Transportation (TxDOT) by the report producer. TxDOT and the report producer jointly own all rights, title, and interest in and to all intellectual property developed under TXDOT's contract with the report producer. The report may be cited and brief passages from this publication may be reproduced without permission provided that credit is given to both TXDOT and the report producer. Permission to reprint an entire chapter, section, figures or tables must be obtained in advance from either the Supervisor of the Archeological Studies Branch, Environmental Affairs Division, Texas Department of Transportation, 125 East 11th Street, Austin, Texas, 78701 or from the report producer. 


\section{National Register of Historic Places (NRHP) Eligibility Testing of 41 BX1749, Bexar County, Texas}

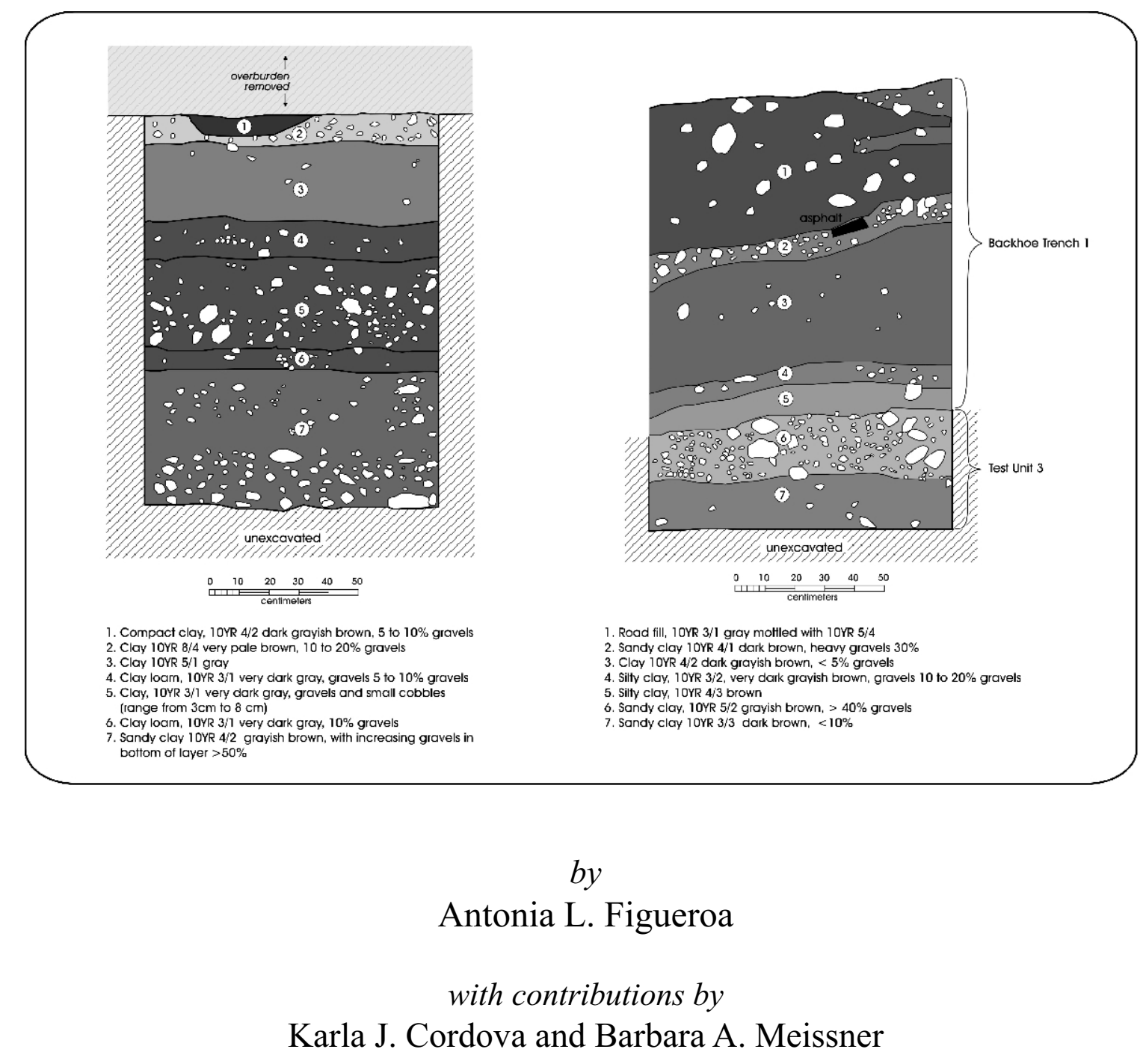

Prepared for:

HNTB Corporation

85 N.E. Loop 410 Ste. 304

San Antonio, Texas 78216
Prepared by:

Center for Archaeological Research The University of Texas at San Antonio Archaeological Report, No. 379

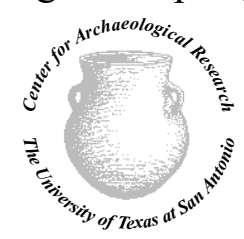




\title{
National Register of Historic Places (NRHP) Eligibility Testing of 41BX1749, Bexar County, Texas
}

\author{
by \\ Antonia L. Figueroa \\ with contributions by \\ Karla J. Córdova and Barbara A. Meissner
}

Texas Antiquities Committee Permit No. 4679, CSJ: 521-04-204; 521-05-119; 521-05-093; 017-02-060

Principal Investigator

Jennifer L. Thompson

Prepared for:

HNTB Corporation

85 N.E. Loop 410 Ste. 304

San Antonio, Texas 78216

For use by:

Environmental Affairs Division

Texas Department of Transportation

Austin, Texas
Prepared by:

Center for Archaeological Research

The University of Texas at San Antonio

Archaeological Report, No. 379

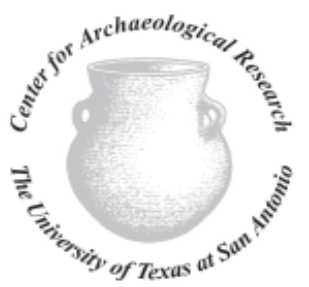





\begin{abstract}
:
The Center for Archaeological Research (CAR) of the University of Texas at San Antonio conducted National Register of Historic Places eligibility testing at archeological site 41BX1749 located in southwest Bexar County, Texas. The work was completed under a contract with the HNTB Corporation (contracted by TxDOT) as part of the proposed Loop 410 Southwest Improvement Project, San Antonio, Bexar County, Texas. Testing of the site included mechanical auger boring, backhoe trenching and three 1-x-1 meter test units. The archeological work was conducted under Texas Antiquities Committee permit \#4679 with Jennifer L. Thompson serving as Principal Investigator. Testing concluded that 41BX1749 is a multi-component site that includes a historic and prehistoric component. The historic component dates to the late $19^{\text {th }}$ or early $20^{\text {th }}$ century. The prehistoric component could not be dated. However, the component was found to be intact in one of the three test units and CAR recommends that the deposits are eligible for listing on the NRHP based on National Register evaluation criterion D.
\end{abstract}

All artifacts collected and records generated during this project are curated at the Center for Archaeological Research according to Texas Historical Commission guidelines. 


\section{Table of Contents:}

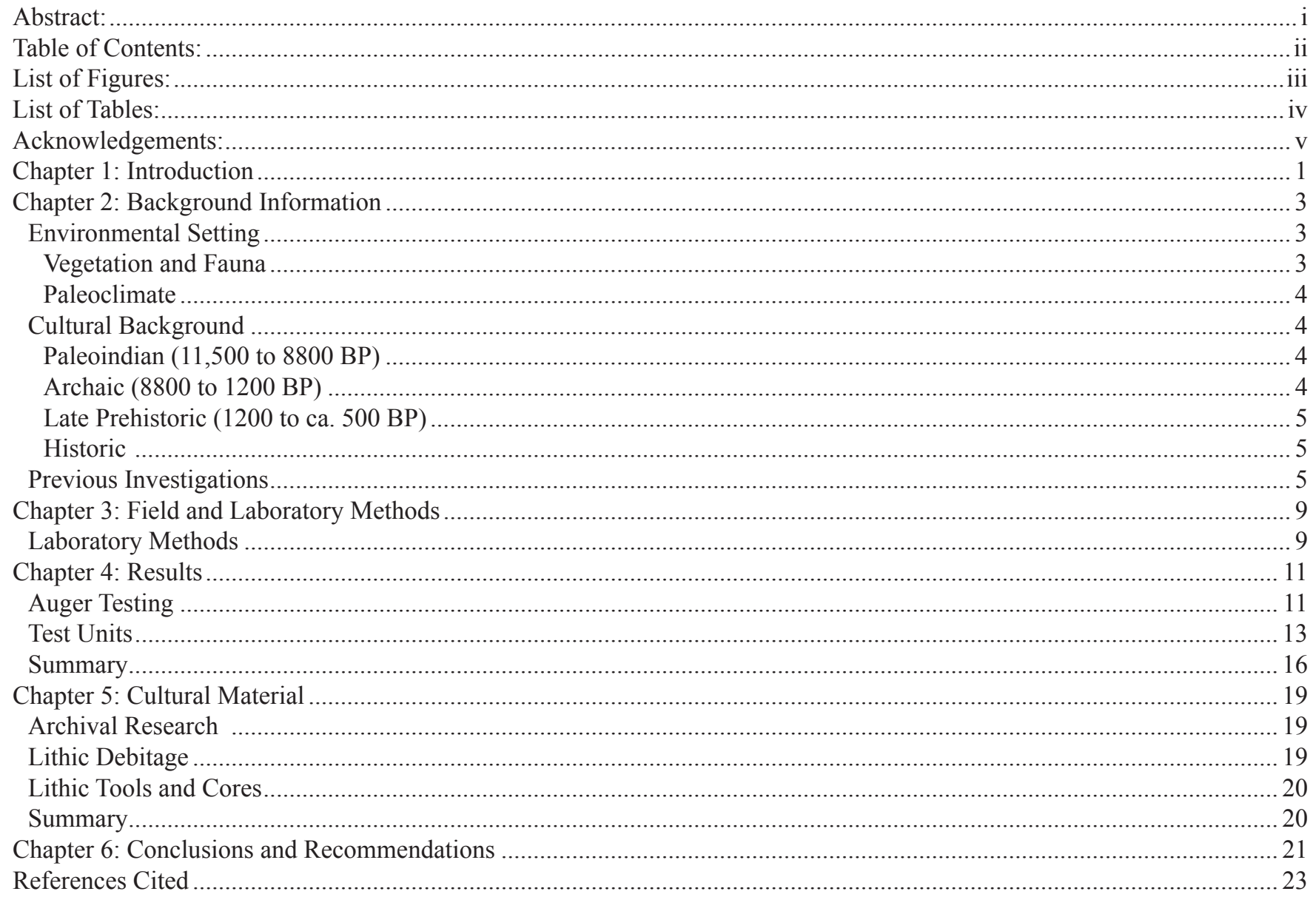




\section{List of Figures:}

Figure 1-1. Project area on the Culebra Hill, 7.5 Minute Series, USGS quadrangle map..................................................... 1

Figure 4-1. Project area depicting mechanical auger tests, backhoe trenches and test unit excavations.................................. 11

Figure 4-2. The field crew pin flagging the mechanical auger tests (western line). ........................................................... 12

Figure 4-3. Mechanical auger tests marked with pin flags (eastern line). .......................................................................... 12

Figure 4-4. Reopening Backhoe Trench 13 and scraping 25 centimeters of fill for Test Unit 1 placement............................ 13

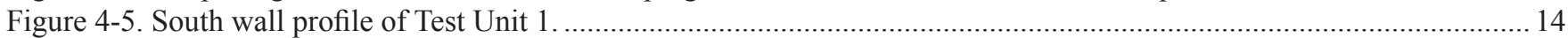

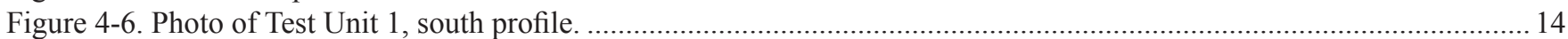

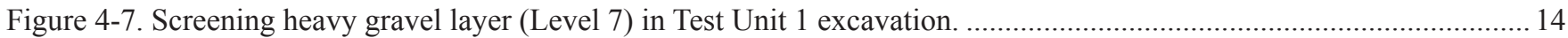

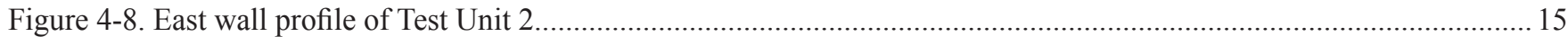

Figure 4-9. Intact deposits (at $110 \mathrm{cmbd}$ ) in Test Unit 2, note FCR and unmodified cobbles.............................................. 16

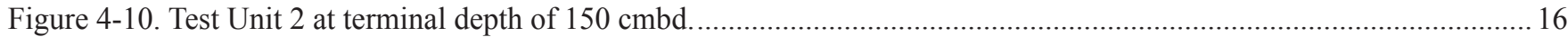

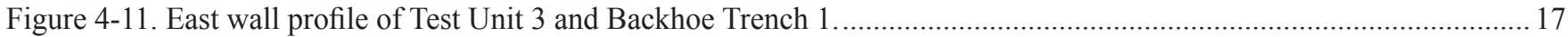

Figure 5-1. Lithic core (A) and retouched flake (B and C) tools recovered from test unit excavations................................220

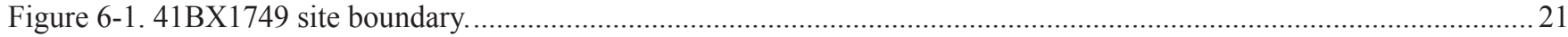




\section{List of Tables:}

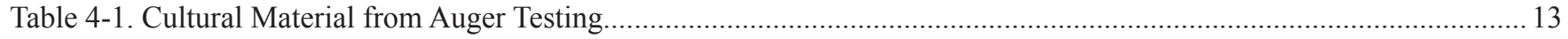

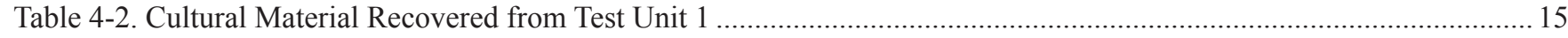

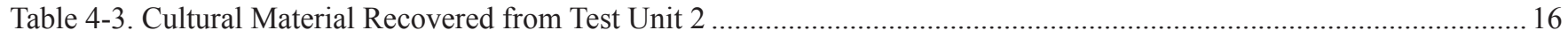

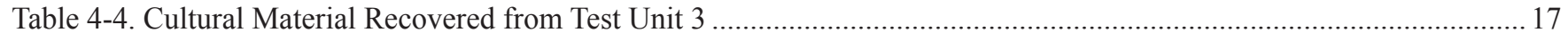




\section{Acknowledgements:}

The successful completion of this project would not have been possible without contributions from a number of people. The fieldwork would not have been completed without the hard work of the field crew that consisted of Nate Devito, Jon Dowling, and Jason Perez. Alamo Backhoe Services and Rocky Hill Equipment provided the equipment and operators for backhoe trench excavations and mechanical auger testing. Thanks to Michelle Dippel and Robert Clarkson of the HNTB Corporation. Also, thanks to Al McGraw and Gina Salazar of TxDOT. Leonard Kemp and Bruce Moses prepared the figures for this report. Bruce Moses served as the technical editor. Jennifer L. Thompson served as the Principal Investigator and aided tremendously with field logistics and report preparation. Dr. Steve Tomka, CAR Director, and Dr. Raymond Mauldin, CAR Assistant Director, provided guidance throughout this project. 



\section{Chapter 1: Introduction}

In October and November of 2007, the Center for Archaeological Research (CAR), The University of Texas at San Antonio was contracted by the HNTB Corporation to conduct National Register of Historic Places (NRHP) eligibility testing of 41BX1749 in southwest Bexar County, Texas (Figure 1-1). The Texas Department of Transportation (TxDOT), as part of the Loop 410 Southwest Improvements Project, has contracted HNTB. The Loop 410 Southwest Improvements Project consists of construction designed to increase the capacity of the highway, operational improvements at interchanges, and service improvements and ramp revisions that will accommodate future increases in traffic volume. All work done by the CAR was conducted under the terms and conditions of the First Amended Programmatic Agreement among the Federal Highway Administration (FHWA), TxDOT, the Texas Historical Commission (THC) and the Advisory Council on Historic Preservation (2005), as well as the Memorandum of Agreement (MOA) between TxDOT and THC. report (Meissner et al. n.d.). The site was initially manifested as lithic debitage and burned rock, encountered in the profile of Backhoe Trench 13, a trench excavated within the north ROW of US 90 near Medio Creek (see Meissner et al. n.d). Our subsequent work showed that the site minimally covers $2,237 \mathrm{~m} 2$, being bound on the north by a fence line and to the south by the Loop 410 access road. The site is approximately 60 meters in length. Cultural material, recovered down to $155 \mathrm{cmbs}$, consisted of both historic and prehistoric artifacts. Recovered historic material included unidentified metal and glass fragments, cut nails, and late 19th or early 20th century ceramics. This material was primarily isolated between 30 and $40 \mathrm{cmbs}$ in Test Unit 1. Prehistoric material included lithic debitage, tools, and cores, as well as burned rock. No features were encountered, but the presence of burned rock suggests that features were, at one time, present. High densities of prehistoric material, isolated between two gravel layers, were present in Test Unit 2 between 100 and 120 cmbs. While we lack chronological information, our testing
Site $41 B X 1749$ is located within the current right-of-way along US 90 on a T1 terrace of Medio Creek. The site will be impacted by the Loop 410 Improvements. The area of potential effects (APE) is located on US 90 and extends $1.8 \mathrm{~km} \mathrm{(1.1}$ miles) to the west and $2.6 \mathrm{~km}(1.6$ miles) to the east. Archeological investigations were conducted under Texas Historical Commission (THC) permit \# 4679, with Jennifer L. Thompson serving as the Principal Investigator.

The significance testing performed by CAR at $41 \mathrm{BX} 1749$ was to: 1) determine the extent, nature, and depth of the deposits; and 2) determine if the site warrants listing on the National Register of Historic Places (NRHP) and/or designation as a State Archeological Landmark (SAL). The site was discovered during the archeological survey of the Loop 410 Southwest Improvements Project, the results of which are being summarized in a separate

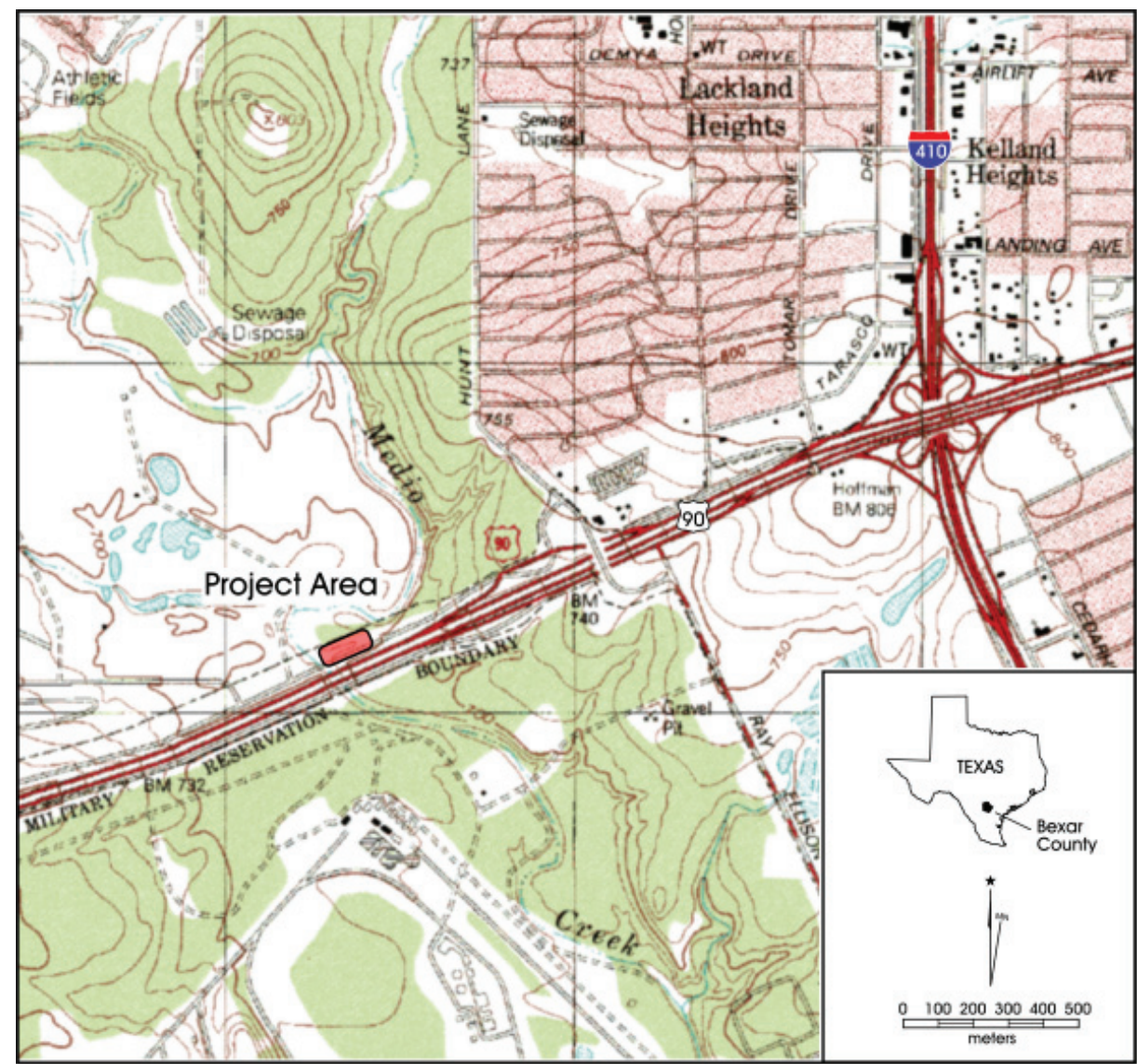

Figure 1-1. Project area on the Culebra Hill, 7.5 Minute Series, USGS quadrangle map. 
results suggest that this prehistoric component is intact. This deposit contained burned rock, lithic debitage, and stone tools. Due to the intact nature of the prehistoric deposit, CAR recommends that site 41BX1749 is eligible for listing on the NRHP under criterion D.

This report is divided into six chapters. Chapter 2 provides the background information for the project area, including environment, culture chronology and previous archeology. Chapter 3 outlines the field and laboratory methods implemented during project, while Chapter 4 discusses the results of the testing. The cultural material is discussed in Chapter 5 and summary and recommendations are presented in Chapter 6. 


\section{Chapter 2: Background Information}

\author{
Karla J. Córdova and Barbara A. Meissner
}

This chapter provides background information for the greater Loop 410 survey project area. Included is an overview of the regional environment including paleoenvironment, a review of cultural history in the area, a summary of previous archeology research projects in or near the APE, and a brief summary of previously recorded sites within two $\mathrm{km}$ of the APE.

\section{Environmental Setting}

Bexar County is located at the juncture of three major geographic regions: the Edwards Plateau, the Blackland Prairie, and the South Texas Brush Country (Nickels et al. 1997). The Edwards Plateau, comprising the northern part of the county, gradually slopes to the southeast and ends in the Balcones Escarpment (Black 1989: Figure 6-1). A strip of the Blackland Prairie runs below the escarpment across most of the central portion of the county. South of the Blackland Prairie, in southern Bexar County, is the beginning of the South Texas Plain. The project area lies within the Blackland Prairie physiographic area, in what was once a tall grass prairie cut by many creeks and rivers (Forrestal 1935:14; Hatcher 1932:55; Potter et al. 1995:12, 23). In Bexar County, the Balcones Escarpment is drained by the San Antonio and Medina Rivers. The major tributaries in the project area include Leon, Indian, and Medio Creeks (Nickels et al. 1997).

Soils within the project area primarily consist of the Houston Black - Houston and Lewisville-Houston Black associations of deep clayey soils (Taylor et al. 1991). These soils are found on the majority of the uplands in central and southwest Bexar County. The Venus-Frio-Trinity association soils are located near creeks and on lower terraces.

The project area has a modified subtropical and subhumid climate with cool winters and hot summers (Norwine 1995). January highs average $60.8^{\circ} \mathrm{F}$ and lows average $37.9^{\circ} \mathrm{F}$. July highs average $95.0^{\circ} \mathrm{F}$ and lows average $75.0^{\circ}$ F (Bomar 1983:214-222). Annual precipitation in the area averages 29.13 inches, although there is a great deal of yearly variation. Rainfall tends to occur in a bimodal pattern with peaks between May and June and September and October (Bomar 1983:56). Sudden downpours along the Balcones Escarpment are not uncommon, where thin clay soils and limestone outcrops contribute to massive runoff into creeks, in turn leading to flash floods in the southern two-thirds of the county (Bomar 1983:65).

\section{Vegetation and Fauna}

Bexar County represents an ecotone, an area where several different biotic provinces meet (Blair 1950), and as such there is a great variety of both plant and animal species. Only the most common are mentioned below.

According to Gould (1975), the prairie area south of the escarpment was once dominated by tall grass species such as little bluestem (Schizachyrium scoparium), big bluestem (Andropogon gerardi), and indiangrass (Sorghastrum nutans). Tree species common to the drainage areas included various species of oaks (Quercus spp.), elms (Ulmus spp.), cottonwoods (Populus spp.), hickories (Carya spp.) and native pecan (Carya illinoinensis), while mesquites (Prosopis spp.) and hackberries (Celtis spp.) are the most common upland trees. The original vegetation of the area has changed dramatically due to overgrazing in the past, as well as suppression of range-fires, urban development, and introduction of foreign species. Today the small types of brush that once dotted the grasslands have largely taken over undeveloped land and invasive species such as chinaberry (Melia azedarach) are common. The undeveloped landscape is now dominated by whitebrush (Aloysia gratissima), mesquite (Prosopis sp.), huisache (Acacia smallii), and hackberry (Celtis occidentalis sp.).

The fauna around the project area is diverse. Twenty-nine species of mammals and 95 species of birds can be found in the area (Cleveland and McCain 1992:1-5, 26-28), as well as numerous varieties of fish and reptiles. Common mammals include several varieties of native rats, especially packrats (Neotoma spp.) and cotton rats (Sigmodon hispidus); cottontail rabbits (Sylvilagus spp.); whitetail deer (Odocoileus virginianus); coyotes (Canis latrans); and bobcats (Felis rufus). In the creeks are catfish (Ictalurus spp.), bullhead catfish (Pylodictus olivaris), and gar (Lepisosteus spp.). Both softshell (Trionyx spp.) and slider (Trachemys spp.) turtles are very numerous. Changes in the ecology due to the presence of a large human population in the area have resulted in the loss of several large mammal species present during historic times, such as antelope (Antilocapra americana), bear (Ursus americanus), wolf (Canis lupus), puma (Puma concolor), and bison (Bison bison) (Weniger 1997). 


\section{Paleoclimate}

An excellent discussion of recent reconstruction of paleoclimate in Texas is presented by Greaves et al. (2002). A brief summary of that information follows.

Until recently, only a general idea of the post-Pleistocene paleoclimate in Central Texas was possible, based largely on pollen from a few peat bogs, and vegetation found in packrat nests in arid areas of West Texas (Bryant and Shafer 1977). In recent decades, however, a number of more detailed studies have been completed, analyzing data sets that included pollen, phytoliths, oxygen isotopes and faunal remains. These studies allow a more refined view of climate change since the end of the Pleistocene (Greaves et al. 2002:13). The following is based on Figure 10 in Greaves et al. (2002:17) and the relevant discussion (Greaves et al. 2002:15-18)

Beginning at the time of the first known human occupation in Texas (ca. 11,000 BP), the current data for paleoclimate in Texas indicates a climate cooler and wetter than present, with cold-adapted tree species such as spruce (Picea spp.) present in Patschke Bog (located about $320 \mathrm{~km}$ (200 miles) NE of the project area) (Bousman 1998, Nickels and Mauldin 2001).

In the early Holocene, between 10,000 and $8000 \mathrm{BP}$, pollen studies indicate that woodlands representing a mesic climate) and grasslands (indicating a xeric climate) succeeded each other in a series of fluctuations during which grasslands gradually came to dominate. The Middle Holocene (ca. 8000 to $4000 \mathrm{BP}$ ) appears to have been a very dry period, although there appear to have been some fluctuations and occasional wetter periods. In particular, the data from a number of sources indicate that there was a substantial mesic period between ca. 6500 to 5000 BP (Greaves et al. 2002:17) becoming much dryer by the end of the period.

In the late Holocene (4000 BP to the present), the various data sets do not agree as well as they did for earlier periods (Greaves et al. 2002:18), suggesting more regional variation than had been seen before that time. Pollen studies show a very dry period at the beginning of the Late Holocene followed by a relatively mesic period ca. $3000 \mathrm{BP}$ and a somewhat dryer period about $1000 \mathrm{BP}$. Since ca. $750 \mathrm{BP}$ the climate has been relatively mesic.

\section{Cultural Background}

Though Bexar County lies at the boundary between the Central Texas and South Texas Archeological Regions, as defined by Black (1989a, 1989b), this report will use the culture prehistory defined for Central Texas. A more detailed culture prehistory for the region can be found in Collins (1995) and Hester (1995).

The cultural history of Bexar County is usually divided into four periods: Paleoindian, Archaic, Late Prehistoric, and Historic. Some of these has been divided into subperiods, but for the purposes of this report only a very general overview of the cultural past of Bexar County is needed.

\section{Paleoindian (11,500 to 8800 BP)}

The earliest identified prehistoric remains in Bexar County are those of the people who made the highly distinctive Clovis spear points. These points have been found in several sites in the county, including the Pavo Real site on Leon Creek upstream of the project area (Collins et al. 2003). Folsom points, the successor to Clovis, have been found at Pavo Real, and at St. Mary's Hall (41BX229; Hester 1979, 1990). Late Paleoindian point types include Plainview, Golondrina, Dalton, and San Patrice (Greaves et al. 2002:19).

The lifestyle of the Clovis and Folsom people appeared to be highly nomadic. These two point styles, as well as associated artifacts, are widely distributed over much of North America. As the Late Paleoindian period began after about 9000 BP, however, a myriad of localized spear point types can be seen across the continent, suggesting that, as the last remnants of the Pleistocene faded, people, though still highly mobile, limited their wanderings to a specific area. Diversity in the projectile points and development of regional tool kits in this period across North America suggest that hunter-gatherer groups began to settle and adapt to the specific landscape in which they found themselves.

\section{Archaic (8800 to 1200 BP)}

During the long period of the Archaic, the inhabitants of Bexar County lived as hunter-gatherer groups that maintained an "annual round" within a given area, moving from one campsite to another as each food type became available during the year, adapting to climate changes (see above) and developing different technologies (Collins 1995:383-385; Greaves et al. 2002:19). Plant gathering appears to have become a more important part of the subsistence pattern in this period, and was probably even more important during more xeric periods. In Central Texas earth ovens heated by hot limestone rocks were used to cook a variety of plant foods that were otherwise not edible, such as the roots of sotol, and yucca (Collins 1995: 383). Remains of these ovens, usually called "burned rock middens", can be found near water courses all over Central Texas. 
The Archaic is usually divided into three sub-periods: Early, Middle, and Late, with archeologists differing somewhat in details of the timing of these sub-periods. Population in Central Texas seems to have increased steadily throughout the Archaic and point types changed over time as well. Early Archaic points, such as Angostura, Gower, and Early Corner-notched, are seen in several sites near the project area, including 41BX47 on Leon Creek, not far south of Pavo Real.

Middle Archaic point types include Nolan, Bell, and Travis. The large number of sites dating to this period suggests that the population was increasing rapidly.

In the early part of the Late Archaic, point types include Pedernales, Marshall, Montell and Castroville, with a shift to smaller points such as Frio and Ensor types in the later part of the sub-period. In the Late Archaic, cemeteries become much more common throughout the state (Nickels et al. 1998). The apparent use of areas designated as cemeteries has been interpreted as an increase in territoriality due to reduced mobility caused by increased population.

A late subperiod or interval of the Late Archaic is frequently referred to as the Terminal Archaic or Transitional Archaic. Weir (1976) defines the Terminal Archaic as 1650-1150 bp, while Turner and Hester (1993) cite data placing the Transitional Archaic as 2250-1250 bp. Although Hester may lump current data into a Late Archaic period, he cautions that more evidence will likely result in what may be termed as a "Terminal Archaic" period during the latter part of the Late Archaic in South Texas. This Terminal Archaic period is represented by diagnostics such as Ensor, Frio, and Matamoras points which appear to overlap the Late Archaic and the subsequent Late Prehistoric period (Hester 1995:442). Weir (1976) believes this marked a transition period to localized area sites, a disappearance of burned rock middens and bison, and a reappearance of highly mobile hunters and gatherers. Others (Black and McGraw 1985; Skelton 1977) argue that in some locations burned rock middens did not disappear and sites were more intensely occupied during the Transitional Archaic period.

\section{Late Prehistoric (1200 to ca. 500 BP)}

The shift to the Late Prehistoric period is marked by the introduction of the bow and arrow, representing a major shift in hunting technology. The period includes two Phases: The Austin Phase and the Toyah Phase.

It is suggested at the beginning of this period environmental conditions were warm and dry. More mesic conditions appear to accelerate after 1,000 B.P. (Nickels and Mauldin 2001). Subsistence practices remain relatively unchanged, especially during the Austin Phase. Projectile point styles associated with the Austin phase include Edwards and Scallorn types while in the Toyah phase the Perdiz projectile point is prevalent (Collins 1995).

Edwards, Scallorn, and later the Perdiz point types are associated with this period. During the Toyah Phase some Native Americans in Texas adopted ceramic technology. The type of prehistoric ceramics found in Bexar County remained a plain brownware (usually called Leon Plain) until the introduction of more highly fired and highly decorated ceramics introduced by the Spanish after 1600 A.D.

\section{Historic}

Descriptions of the San Antonio Springs were reported by Damián Massanet as early as 1691 (Brune 2001). Fray Antonio de San Buenaventura y Olivares was impressed by the many springs and creeks in the area (Chipman 2001). Olivares began a campaign to get a mission established in the area, and succeeded after almost 10 years. In 1718, the mission San Antonio de Valero and Presidio San Antonio de Bexar were established near San Pedro Springs. The mission was moved to its current location ca. 1724 while the presidio was moved across the river near the new villa of San Fernando de Bexar. These three institutions were the foundations of the city of San Antonio (Fehrenbach 2004).

For a long time the project area was part of the wilderness outside the settlement of San Antonio. It was not until after Texas became part of the United States that immigrants, largely from the southeastern states, began to create farms around the city. After the Civil War, the city became one of the foci for a wave of German immigrants whose farms soon filled in the remaining undeveloped land in the county (Fehrenbach 2004). Aerial photographs of the project area taken in the late 1950s (Taylor et al. 1991: Map 52) show these prairie lands were being farmed before urbanization overtook the area, a process that began in the 1970s.

\section{Previous Investigations}

A large part of Lackland AFB and the Medina Annex, both of which are immediately adjacent to parts of the APE, were surveyed and later eight sites were further tested (Nickels et al. 1997; Houk and Nickels 1997). The earliest archeological survey along Medio Creek occurred in 1970 by McGraw (THC 2007). Seventy-one sites were recorded during the first phase of the project (Nickels et al. 1997). Cultural materials 
indicated Early Archaic to Late Prehistoric occupations. Two of the sites tested by CAR, sites 41BX1102 and 41BX1103, were recommended as eligible for listing on the National Register of Historic Places (NRHP). Both 41BX1102 and 41BX1103 are less than 500 meters south of the APE on US 90 (Figure 2-3).

- 41BX1002. Site 41BX1002, roughly $1720 \mathrm{~m}$ west of Loop 410, is a multi-component site roughly 20,800 $\mathrm{m} 2$ with both prehistoric and historic features. It was recorded in 1993 (De Vore 1993), and reexamined during the Medina Annex Survey in 1994 (Nickels et al. 1997). The historic component includes the foundations of two historic stone buildings. The historic occupation partially disturbed a prehistoric component that yielded an Early Archaic dart point. The 1994 assessment did not recommend the site for listing on the NRHP or for designation as an SAL.

- $41 \mathrm{BX} 465$. Site $41 \mathrm{BX} 465$ is roughly $640 \mathrm{~m}$ north of US 90. It was recorded in 1977, described as a scatter of chert flakes, cores, and burned rock on a terrace above Medio Creek. The examination was limited to a surface inspection, and the recorder recommended that the site be tested (THC 2007). The eligibility status of the site is not known.

- 41BX1070. Site 41BX1070 is roughly $1370 \mathrm{~m}$ west of Loop 410. It was recorded during the Medina Annex Survey in 1995, on a bluff near an unnamed tributary of Medio Creek. It was described as a lithic procurement site, about $1400 \mathrm{~m} 2$, with a large assemblage of early reduction stage lithics. A single shovel test indicated that the deposit was limited to the surface. Nevertheless, the site appeared relatively intact and undisturbed and the preliminary assessment was that the site was potentially eligible for listing on the NRHP and/or for designation as an SAL (Nickels et al. 1997).

- 41BX1071. Site 41BX1071 is roughly $940 \mathrm{~m}$ west of Loop 410. It was recorded during the Medina Annex Survey in 1994, on uplands above Medio Creek. It was described as a lithic procurement and camp site, measuring about $1400 \mathrm{~m} 2$, with a large assemblage of early reduction stage lithics, and a few burned rocks. An Edgewood dart point found on the surface is from the Transitional Archaic (ca. 2300-1300 BP). The site had been damaged by road construction and surface clearing. Nevertheless, portions of the site appeared relatively intact and undisturbed and the preliminary assessment suggested that the site was potentially eligible for listing on the NRHP and/or for designation as an SAL (Nickels et al. 1997).
- 41BX1078. Site 41BX1078 is roughly $1480 \mathrm{~m}$ west of Loop 410. It is a small lithic procurement site of about $700 \mathrm{~m} 2$, with artifacts limited to the surface. There is little evidence of disturbance at the site. The preliminary assessment was that the site was potentially eligible for listing on the NRHP and/or for designation as an SAL (Nickels et al. 1997).

- 41BX1086. Site 41BX1086, roughly $1970 \mathrm{~m}$ west of Loop 410, was identified during the Medina Annex Survey in 1994, on a terrace of Medio Creek, and described as a lithic procurement area and open camp site with an area of about $900 \mathrm{~m} 2$. The artifact density on the surface was very high and a shovel test showed that another component was present at $40-50 \mathrm{cmbs}$. The site showed few signs of disturbance. The preliminary assessment was that the site was potentially eligible for listing on the NRHP and/or for designation as an SAL (Nickels et al. 1997).

- 41BX1087. Site 41BX1087, roughly $1590 \mathrm{~m}$ west of Loop 410, was recorded during the Medina Annex Survey in 1994, on a terrace of Medio Creek, and described as a small open camp site with an area of about $315 \mathrm{~m} 2$. Artifact density on the surface, including debitage from all stages of lithic tool manufacture and large amounts of burned rock, was high and a shovel test indicated the component extended to $20 \mathrm{cmbs}$. A Matamoros point was found on the surface, indicating a Late Archaic date for the component. The site showed little evidence of disturbance. The preliminary assessment was that the site was potentially eligible for listing on the NRHP and/or for designation as an SAL (Nickels et al. 1997).

- 41BX1088. Site 41BX1088, located about $1360 \mathrm{~m}$ west of Loop 410, is a huge site, covering 166,000 m2 on an upland ridge above Medio Creek. It was recorded during the Medina Annex Survey in 1994 and described as a large open campsite and lithic procurement area. Large amounts of fire-cracked rock, cores, bifaces, and debitage, indicating all stages of lithic tool manufacture, and some ground stone were observed on the surface, especially on the higher elevations of the site. During the survey, two Guadalupe bifaces, as well as Pedernales and Lange dart points, were recovered. These diagnostic artifacts indicate occupation from the Early Archaic through the Late Archaic periods. The site was tested in 1996. Test units were dug to 100 cmbs and all had artifacts throughout, though artifact density dropped sharply below $20 \mathrm{cmbs}$. Artifacts recovered during the testing included Archaic dart points such as Pedernales, Darl, Edgewood, Ensor, Frio 
and Fairland types as well as Late Prehistoric artifacts such as Scallorn and Perdiz arrow points and Leon Plain ceramics. With the exception of the two Guadalupe tools and the Pedernales point, the diagnostic artifacts indicated a Transitional Late Archaic to Late Prehistoric occupation period. Two features were located on the surface, both of which were alignments of large stones. Feature 1 consisted of three oval stone alignments one of which measured $2.5 \times 3.5 \mathrm{~m}$. Feature 2 consists of large rocks arranged into parallel lines about $3 \mathrm{~m}$ long. No date could be assigned to these features. The site has been impacted by the construction of fire roads and fire breaks which appear to have removed about 20 to $30 \mathrm{~cm}$ of sediments. Otherwise, the only impact to the site that was visible was erosion. The testing resulted in a recommendation that the site is eligible for listing on the NRHP and/or for designation as an SAL (Nickels et al. 1997).

- 41BX1089. Site 41BX1089 is roughly $890 \mathrm{~m}$ west of Loop 410. It was recorded during the Medina Annex Survey in 1994, on the uplands overlooking Medio Creek. It was described as a lithic procurement site, measuring about $1400 \mathrm{~m} 2$, with a large assemblage of early reduction stage lithics. A shovel test indicated that the deposit was limited to the surface. Nevertheless, the site appeared relatively intact and the preliminary assessment was that the site was potentially eligible for listing on the NRHP or for designation as an SAL (Nickels et al. 1997).

- 41BX1090. Site 41BX1090 is roughly $820 \mathrm{~m}$ west of Loop 410. It was also a lithic procurement site, approximately $1040 \mathrm{~m} 2$ in size, recorded during the Medina Annex Survey in 1994, on uplands overlooking Medio Creek (Nickels et al. 1997). The site was tested in 1996. No diagnostic artifacts were recovered. It was determined that the cultural deposits did not retain sufficient integrity to make the site eligible for listing on the NRHP and/or for designation as an SAL.

- 41BX1102. Site 41BX1102 is roughly $400 \mathrm{~m}$ south of US 90. It is an open camp site located on the T1 terrace above Medio Creek. It measures approximately 13,975 $\mathrm{m} 2$, and was recorded during the Medina Annex Survey in 1994 (Nickels et al. 1997). The site was tested in 1996 (Houk and Nickels 1997). Eight Pedernales points and two possible projectile point blanks were collected from the surface during testing and survey. Shovel testing and test units excavated indicated the possible presence of three components, one at surface, a second one at about $50 \mathrm{cmbs}$ and a third component buried at $70 \mathrm{cmbs}$. Although the eastern half of the site had been impacted by military activities on the base, the western half was relatively undisturbed. The site was determined to be eligible for listing on the NRHP and/or for designation as an SAL (Houk and Nickels 1997).

- 41BX1103. Site 41BX1103 is $260 \mathrm{~m}$ south of US 90. It was described as an open camp site located on the T1 terrace above Medio Creek. It measures approximately 13,115 m2, and was recorded during the Medina Annex Survey in 1994 (Nickels et al. 1997). The testing done in 1996 (Houk and Nickels 1997) found artifacts to at least one meter below the surface. Radiocarbon dating and diagnostic artifacts indicate the site was occupied between about 3600 and 1400 BP. Diagnostic points recovered from the surface included Edgewood, Ensor, Fairland, and Frio, all of which date to the Transitional Archaic (roughly 2300-1300 BP). Although parts of the site are disturbed by military activities, the remainder is relatively undisturbed. The site was determined to be eligible for listing on the NRHP and/or for designation as an SAL (Houk and Nickels 1997).

- 41BX1105. Site 41BX1105 is less than a $100 \mathrm{~m}$ from US 90, located along an intermittent unnamed tributary of Medio Creek. It appears to be a lithic procurement site $1054 \mathrm{~m} 2$, but no diagnostic artifacts were recovered and a shovel test showed that the artifacts were limited to the surface. Nevertheless, the site appeared relatively intact and was assessed as potentially eligible for listing on the NRHP and/or for designation as an SAL (Nickels et al. 1997).

- 41BX1106. Site 41BX1106 is less than a $100 \mathrm{~m}$ from US 90, located on a terrace near Medio Creek. It appears to be a lithic procurement site occupying 840 $\mathrm{m} 2$. No diagnostic artifacts were recovered during its recordation. A shovel test showed that artifact deposits continued to at least $20 \mathrm{cmbs}$. The site appeared relatively intact and the preliminary assessment was that the site was potentially eligible for listing on the NRHP and/or for designation as an SAL (Nickels et al. 1997).

- 41BX1107. Site 41BX1107 is a small open campsite about 1580 m west of Loop 410, on a broad alluvial terrace above Leon Creek and occupies about 168 $\mathrm{m} 2$. The dense artifact concentration on this small site included lithic debris from the latter stages of tool manufacture, and burned rock and a Transitional Archaic Edgewood point. The site has been damaged due to its location on the Lackland AFB golf course. 
However, because it is one of the few relatively intact areas along Leon Creek in this area, the preliminary assessment was that the site was potentially eligible for listing on the NRHP and/or for designation as an SAL (Nickels et al. 1997).

- $41 \mathrm{BX} 1115$. Site $41 \mathrm{BX} 1115$ is a small site $1550 \mathrm{~m}$ west of Loop 410. The site is approximately $30 \mathrm{~m} 2$, recorded during the Medina Annex Survey in 1994, on a terrace above Medio Creek. Two flakes and fire cracked rock were collected during shovel testing. It was recommended that additional subsurface testing be conducted at the site. Furthermore, it was recommended that the site was potentially eligible for listing on the NRHP and/or for designation as an SAL (Nickels et al. 1997).

- 41BX1119. Site 41BX1119 is a lithic procurement site $1750 \mathrm{~m}$ west of Loop 410. Very similar to 41BX1115, the site is approximately $30 \mathrm{~m} 2$, recorded during the Medina Annex Survey in 1994, on a terrace above Medio Creek. A shovel test located no artifacts below the surface. Nevertheless, the site appeared relatively intact and the preliminary assessment was that the site was potentially eligible for listing on the NRHP and/or for designation as an SAL (Nickels et al. 1997).

- 41BX1120. Site 41BX1120 is a small open campsite site $1790 \mathrm{~m}$ west of Loop 410, on a terrace above Medio Creek. The site is approximately $70 \mathrm{~m} 2$, recorded during the Medina Annex Survey in 1994. A shovel test located artifacts to $30 \mathrm{~cm}$ below the surface. The site appeared relatively intact and the preliminary assessment was that the site was potentially eligible for listing on the NRHP and/or for designation as an SAL (Nickels et al. 1997).

- 41BX1130. Site 41BX1130 is located $1730 \mathrm{~m}$ west of Loop 410, on a terrace of Medio Creek. The site is 2400 $\mathrm{m} 2$ and has both historic and prehistoric components. There were no diagnostic prehistoric artifacts located so its temporal affiliation remains unknown. The prehistoric component may have been disturbed by the building of several farm outbuildings, probably in the 1940s. The preliminary assessment was that neither component was eligible for listing on the NRHP and/ or for designation as an SAL, except as a part of an archeological district (Nickels et al. 1997).

- 41BX1131. Site 41BX1131, located $1310 \mathrm{~m}$ southwest of the southern end of the APE on IH 35, was recorded in 1995 during a survey sponsored by the US Corps of Engineers near Mitchell Dam (THC 2007). The site was immediately adjacent to Medio Creek and was partially destroyed by building of a stilling tank for the dam. A scatter of chert flakes and burned rock were observed. There is not enough information available at this time to assess whether the site was eligible for listing on the NRHP and/or for designation as an SAL, so its eligibility status remains unknown (THC 2007).

- 41BX1208. Site 41BX1208, located about $470 \mathrm{~m}$ south of US 90, was recorded during the testing phase of the Lackland AFB/Medina Annex Project in 1996 (Houk and Nickels 1997). It was described as a small lithic procurement site roughly $575 \mathrm{~m} 2$, near Medio Creek. A shovel test showed no artifacts below the surface. The site surface showed evidence of some disturbance, and erosion. The integrity of the site was judged to be insufficient to consider the site eligible for listing on the NRHP and/or for designation as an SAL (Houk and Nickels 1997).

- Rancho San Lucas and the Upper Presido Road. Rancho San Lucas was one of the two ranches belonging to Mission San Jośe y San Miguel Aguayo (McGraw et al. 1998). It is located outside the two km radius but worth mentioning. The location of the rancho lands would have encroached on this portion of Bexar County and all the way to Castroville. It was said to have been over 48,000 acres (McGraw et al. 1998:144). US 90 at this point overlies the 19th century road to Castroville and it closely parallels a portion of the earlier Upper Presidio Road (Berlandier 1980; McGraw et al. 1998). 


\section{Chapter 3: Field and Laboratory Methods}

The site was investigated using a variety of testing methods. These included mechanical auger boring $(n=14)$, test unit excavations $(n=3)$ and backhoe trenching $(n=1)$. Auger tests were excavated east and west (parallel to the road) of Backhoe Trench 13 at five meter intervals. This method aided in determining the horizontal extent of the site within the existing ROW. The auger bit measured 12 inch (approximately $30 \mathrm{~cm}$ ) in diameter. The mechanical auger tests were excavated in six $20-\mathrm{cm}$ levels to $120 \mathrm{cmbs}$. All soils from the $20-\mathrm{cm}$ levels were screened through $1 / 4$ inch hardware cloth. Observations regarding artifact depth and density were recorded on forms that included a description of soil and any inclusions or disturbance encountered at each level. All artifacts collected during auger testing were bagged by level and processed for analysis at CAR. All auger tests locations were recorded with a GPS unit.

The test units were excavated in $10-\mathrm{cm}$ levels by hand and all matrix was screened through $1 / 4$ inch hardware cloth. All cultural material was collected and bagged by level. Appropriate unit level forms were maintained for each unit level. The project archeologist inspected the walls of the excavated units. Selected unit walls were profiled and appropriate notes and digital photographs were taken. All artifacts, faunal and charred organic materials encountered in units were collected for analysis and potential curation as outlined in the original SOW submitted for the Loop 410 Improvements Project.

In addition to BHT 13, Backhoe Trench 1 was excavated during the testing phase. The backhoe trenche was approximately 60 $\mathrm{cm}$ wide, and were excavated to a depth of ca. $150 \mathrm{cmbs}$.
One side of each backhoe trench was scraped down to the desired depth (see Results). Digital photographs were taken of both trenches (BHT 13 and 1). Both backhoe trenches were backfilled at the completion of the fieldwork.

\section{Laboratory Methods}

The cultural materials recovered during testing consisted of prehistoric and historic artifacts. No special samples were collected. The artifacts were brought to CAR's laboratory where they were processed and catalogued according to CAR's standard practices. Processing of recovered artifacts consisted of washing and sorting into appropriate categories (e.g., debitage, lithic tool). Artifacts were washed, air-dried, and stored in archival-quality bags. Acid-free labels were placed in all artifact bags. Each label displayed provenience information and a corresponding lot number laser printed or written in pencil. Artifacts were separated by class and stored in acid-free boxes identified with standard labels. The data were entered into a Microsoft Access database. All artifacts will be permanently curated at CAR.

Field notes, forms, and hard copies of photographs were placed in labeled archival folders. All field forms were completed in pencil. Documents and forms were printed on acid-free paper and any soiled forms were placed in archivalquality page protectors. A copy of this report in Adobe Acrobat ${ }^{\circledR}$ file format and all digital material pertaining to the project, including photographs, were burned onto a $\mathrm{CD}$ and permanently curated with the field notes and documents at the Center for Archaeological Research. 



\section{Chapter 4: Results}

During the testing phase of 41BX1749 fourteen mechanical auger tests, three test units (1-x-1 meter) and one backhoe trench were excavated. This section discusses the results of the testing conducted by the CAR. The mechanical auger tests aided in determining the vertical and horizontal extent of artifacts and identifying disturbed areas. Test Unit 1 was excavated adjoining BHT 13 which was excavated during the survey, while Test Unit 2 was placed on the eastern portion of the site between two positive auger tests. BHT 1 was excavated to explore an intact prehistoric deposit identified in Test Unit 2. An additional test unit (Test Unit 3) was excavated on the site, adjoining BHT 1.

\section{Auger Testing}

Mechanical auger testing was conducted on the site October 19, 2007. Fourteen auger tests were excavated 5 meters apart, east and west of BHT 13 (Figure 4-1, 4-2 and 4-3). A total of $1.19 \mathrm{~m}^{3}$ of soil was excavated during the mechanical auger testing of 41BX1749. Auger testing revealed that the upper
$30-60 \mathrm{~cm}$ of the site was covered with gravel fill. Moreover, the auger tests excavated to the west of BHT 13 (towards the creek) revealed a loose sand fill in the first 40-50 centimeters. One-Call was notified prior to investigations to locate buried utilities. A gas line runs parallel to the access road, just near the fence line. This utility line could account for the sand fill encountered in the western reaches of the site. The soils east of BHT 13 appeared to be less disturbed by utility installations.

Thirty-nine artifacts were recovered and/or observed from the auger tests (Table 4-1). Modern material was not collected but noted on auger test forms. Modern materials (i.e. glass and plastic) were recorded as deep as 100 centimeters below surface (cmbs) in Auger Test 10 and Auger Test 4. The majority of the historical material was encountered west of the BHT 13, with the exception of Auger Test 5 (located east of BHT 13). The historical material recovered included white earthenware, cut nails and amber glass from Levels 3 (40-60 cmbs), $4(60-80 \mathrm{cmbs})$ and $5(80-100 \mathrm{cmbs})$. The majority of prehistoric materials were recorded in the auger tests located

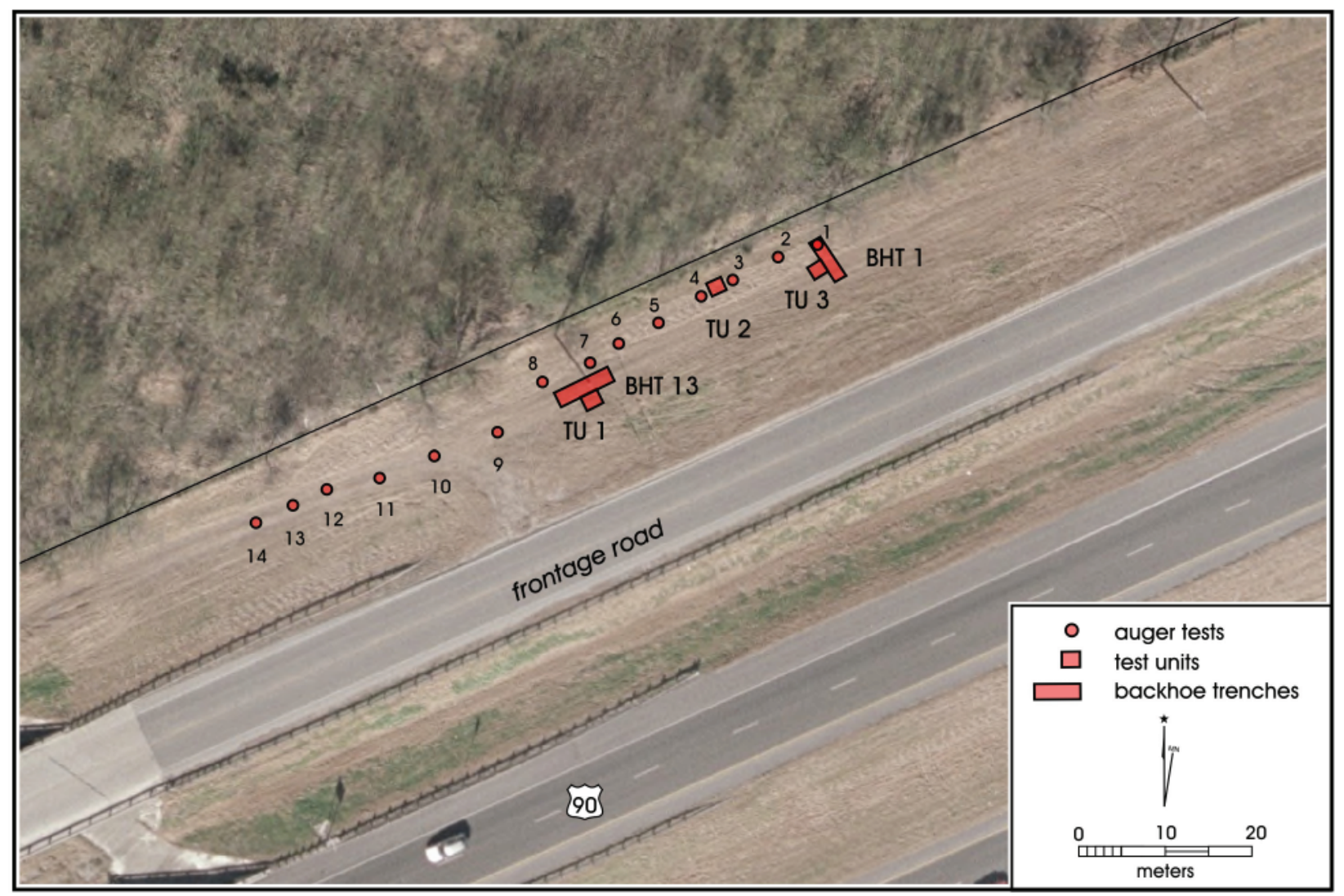

Figure 4-1. Project area depicting mechanical auger tests, backhoe trenches and test unit excavations 


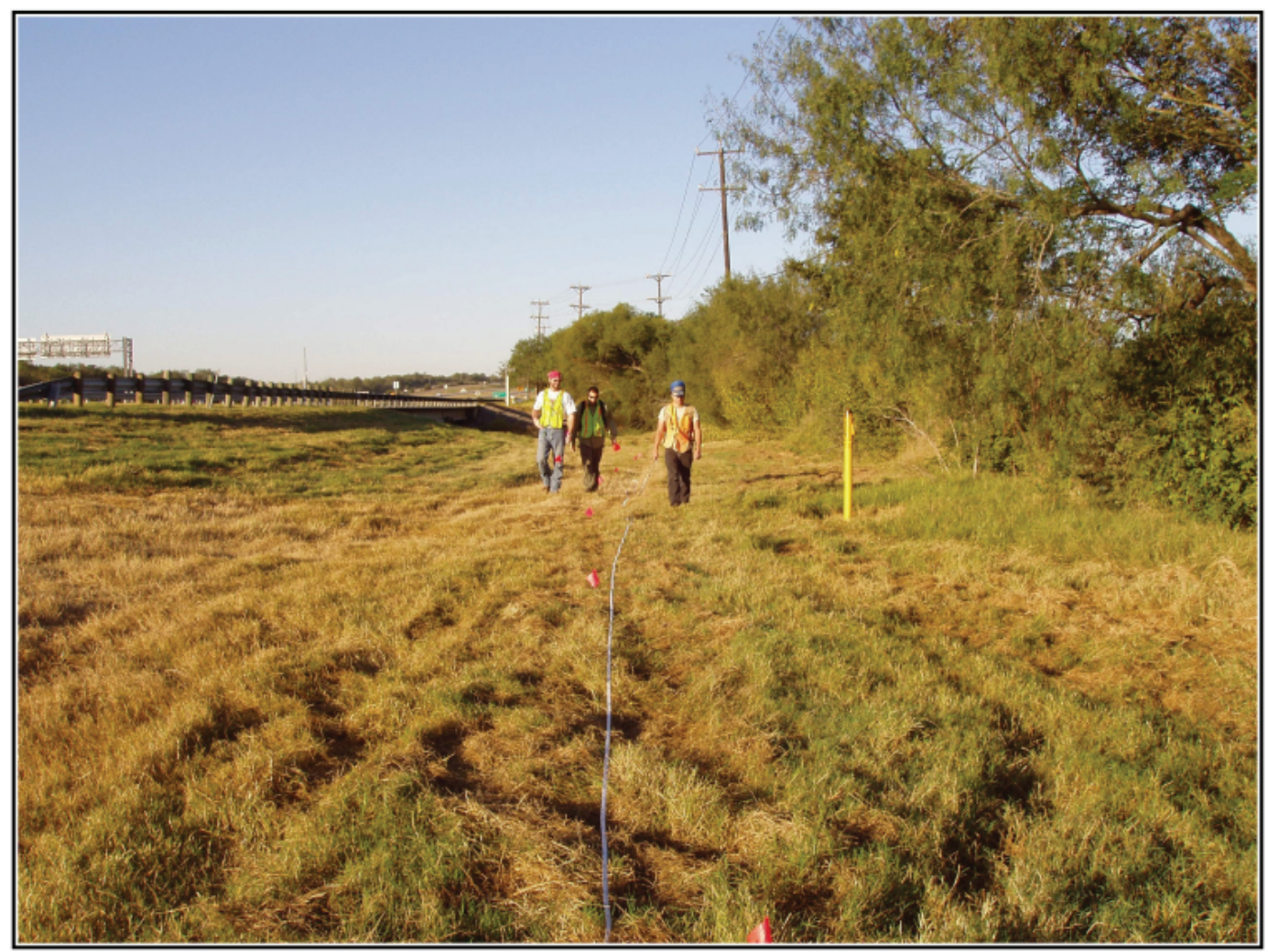

Figure 4-2. The field crew pin flagging the mechanical auger tests (western line).

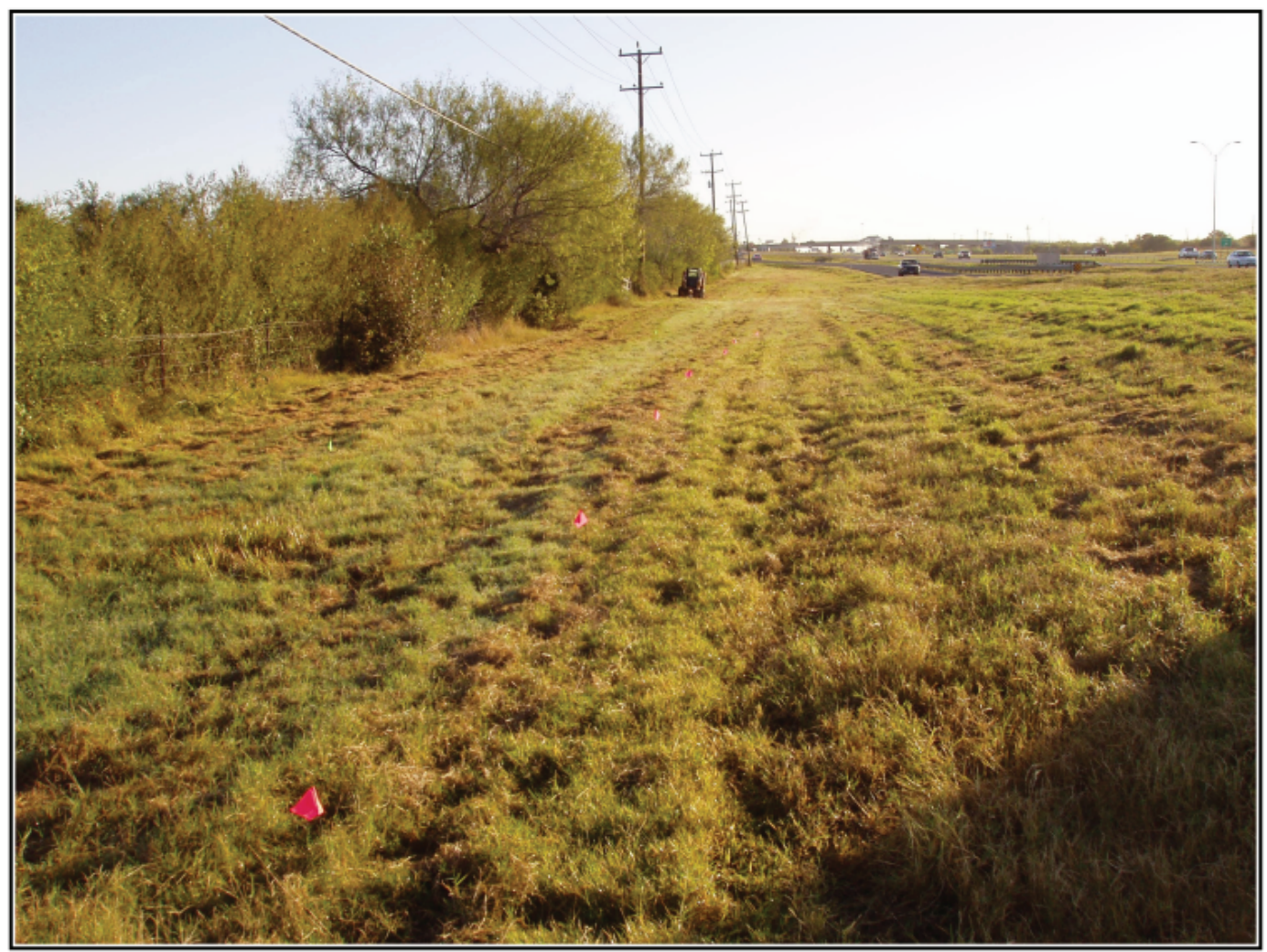

Figure 4-3. Mechanical auger tests marked with pin flags (eastern line). 
Table 4-1. Cultural Material from Auger Testing

\begin{tabular}{|c|c|c|c|c|c|c|}
\hline $\begin{array}{c}\text { Auger } \\
\text { Test }\end{array}$ & Level & $\begin{array}{c}\text { Burned } \\
\text { rock }\end{array}$ & Debitage & Historic & Modern & $\begin{array}{c}\text { Grand } \\
\text { Total }\end{array}$ \\
\hline \multirow{2}{*}{2} & 5 & 0 & 1 & 0 & 0 & 1 \\
\hline & 3 & 0 & 0 & 0 & 1 & 1 \\
\hline 3 & 1 & 0 & 1 & 0 & 0 & 1 \\
\hline \multirow{3}{*}{4} & 1 & 0 & 0 & 0 & 1 & 1 \\
\hline & 5 & 0 & 2 & 1 & 0 & 3 \\
\hline & 6 & 0 & 2 & 0 & 0 & 2 \\
\hline \multirow{5}{*}{5} & 2 & 1 & 1 & 0 & 0 & 2 \\
\hline & 3 & 1 & 0 & 0 & 1 & 2 \\
\hline & 4 & 0 & 0 & 1 & 0 & 1 \\
\hline & 5 & 0 & 1 & 0 & 0 & 1 \\
\hline & 6 & 1 & 3 & 0 & 0 & 4 \\
\hline \multirow{3}{*}{6} & 2 & 0 & 0 & 0 & 1 & 1 \\
\hline & 4 & 1 & 0 & 0 & 0 & 1 \\
\hline & 5 & 0 & 1 & 0 & 0 & 1 \\
\hline 7 & 6 & 0 & 2 & 0 & 0 & 2 \\
\hline 8 & 3 & 0 & 0 & 1 & 0 & 1 \\
\hline \multirow{2}{*}{9} & 4 & 0 & 1 & 0 & 0 & 1 \\
\hline & 5 & 0 & 0 & 2 & 0 & 2 \\
\hline \multirow{4}{*}{10} & 2 & 0 & 0 & 0 & 2 & 2 \\
\hline & 4 & 0 & 2 & 2 & 0 & 4 \\
\hline & 5 & 0 & 0 & 0 & 1 & 1 \\
\hline & 6 & 0 & 0 & 0 & 1 & 1 \\
\hline \multirow{2}{*}{12} & 1 & 0 & 0 & 0 & 1 & 1 \\
\hline & 5 & 0 & 0 & 0 & 1 & 1 \\
\hline 14 & 2 & 1 & 0 & 0 & 0 & 1 \\
\hline $\begin{array}{l}\text { Grand } \\
\text { Total }\end{array}$ & & 5 & 17 & 7 & 10 & 39 \\
\hline
\end{tabular}

east of BHT 13. No features were noted during auger testing. Prehistoric materials recovered included lithic debitage and burned rock. The majority of debitage was recovered from Level $6(n=7)$, in auger tests $(4,5$ and 7$)$ east of BHT 13.

\section{Test Units}

Backhoe Trench 13, excavated during the initial recording of the site, was reopened (see Figure 4-1) and Test Unit 1 was placed adjoining the south wall of the trench. The 1-x-1 meter test unit was excavated in order to investigate the vertical artifact distribution recorded during initial trenching of the site (Meissner et al. 2007). Auger tests revealed that the upper 40 to $50 \mathrm{~cm}$ of the site consisted of gravel fill. Therefore, the first $25 \mathrm{~cm}$ of the test unit was removed with a backhoe (Figure 4-4). In the original scope of work, the test unit excavation was going to include 10 levels but findings in Test Unit 2 prompted the excavation of additional levels. Test Unit
1 was excavated to a depth of $160 \mathrm{cmbd}$. The datum string height was set $5 \mathrm{~cm}$ above ground surface. The amount of soil removed by hand excavations from Test Unit 1 was $1.2 \mathrm{~m}^{3}$.

The first two soil zones in Test Unit 1 consisted of a gravel fill matrix (Figure 4-5). Zone 3 was clay soil (10YR 3/1) with only $5 \%$ gravels. Zones 4 through 6 soils were the same color (10 YR 3/1) but varied in gravel/cobble content (Figure 4-6photo of gravels). Gravels varied in size from $0.3 \mathrm{~cm}$ to $8 \mathrm{~cm}$. These gravel lenses likely represent high energy depositional events. Test Unit 1 excavations terminated in a sandy clay $(10$ YR $4 / 2)$ matrix that contained at least $50 \%$ gravels (Figure 4-7 photo).

Test Unit 1 excavations produced 211 artifacts (Table 4-2). As noted in the soil descriptions, the first two zones (Levels 1-3) were represented by disturbed gravels. Level 4 exhibited a large amount of historical artifacts (glass, ceramics and metal). Few lithics were recovered from Level 4, with only 1 piece of debitage and burned rock. One retouched flake was also recovered from Level 4. The materials from Level 4 were from Zone 3, a clay soil (see Figure 4-4). Metal artifacts consisted of unidentified fragments and cut nails. Ceramic sherds from this level were identified as stoneware $(n=17)$, white earthenware $(n=1)$, porcelain $(n=1)$ and lead glaze $(\mathrm{n}=1)$ types. Lithic debitage and burned rock frequencies remained low in Levels 1-8. In Level 9, there was an increase in debitage $(\mathrm{n}=23)$ and burned rock $(\mathrm{n}=17)$ frequency. This level is in Zone 6 (see Figure 4-4) where there was a slight decrease in gravels. Several lithic debitage pieces showed evidence of being river rolled (a lustrous and polished appearance). In summary, this test unit revealed a historical

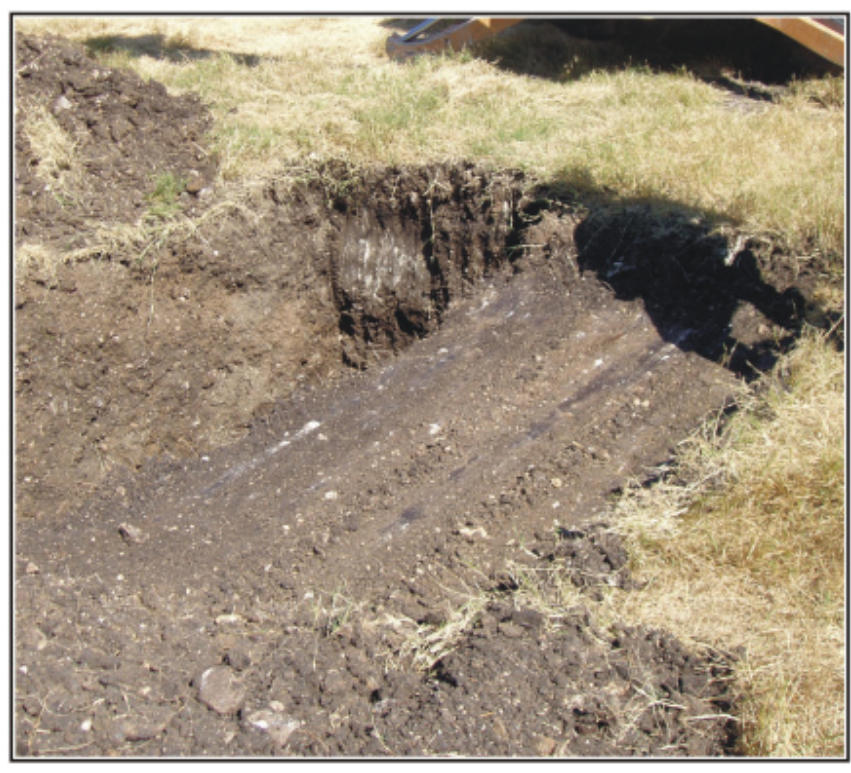

Figure 4-4. Reopening Backhoe Trench 13 and scraping 25 centimeters of fill for Test Unit 1 placement. 


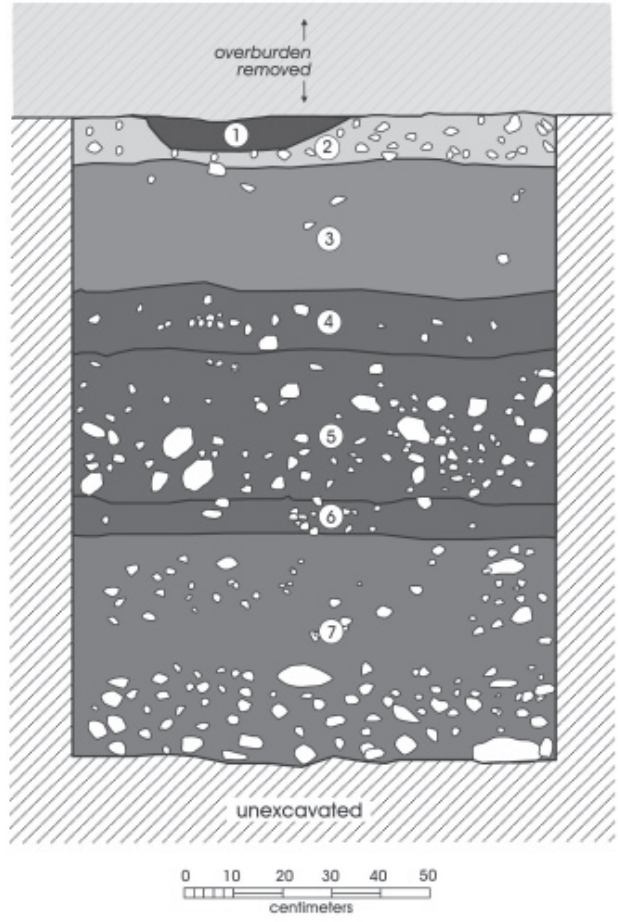

1. Compact clay, 10YR $4 / 2$ dark grayish brown, 5 to $10 \%$ gravels 2. Clay 10YR $8 / 4$ very pale brown, 10 to $20 \%$ gravels

3. Clay $10 Y R 5 / 1$ gray

4. Clay loam, 10YR $3 / 1$ very dark gray, gravels 5 to $10 \%$ gravels

5 . Clay, 10YR $3 / 1$ very dark gray, gravels and small cobbles (range from $3 \mathrm{~cm}$ to $8 \mathrm{~cm}$ )

6. Clay loam, 10YR $3 / 1$ very dark gray, $10 \%$ gravels

7. Sandy clay 10YR $4 / 2$ grayish brown, with increasing gravels in bottom of layer $>50 \%$

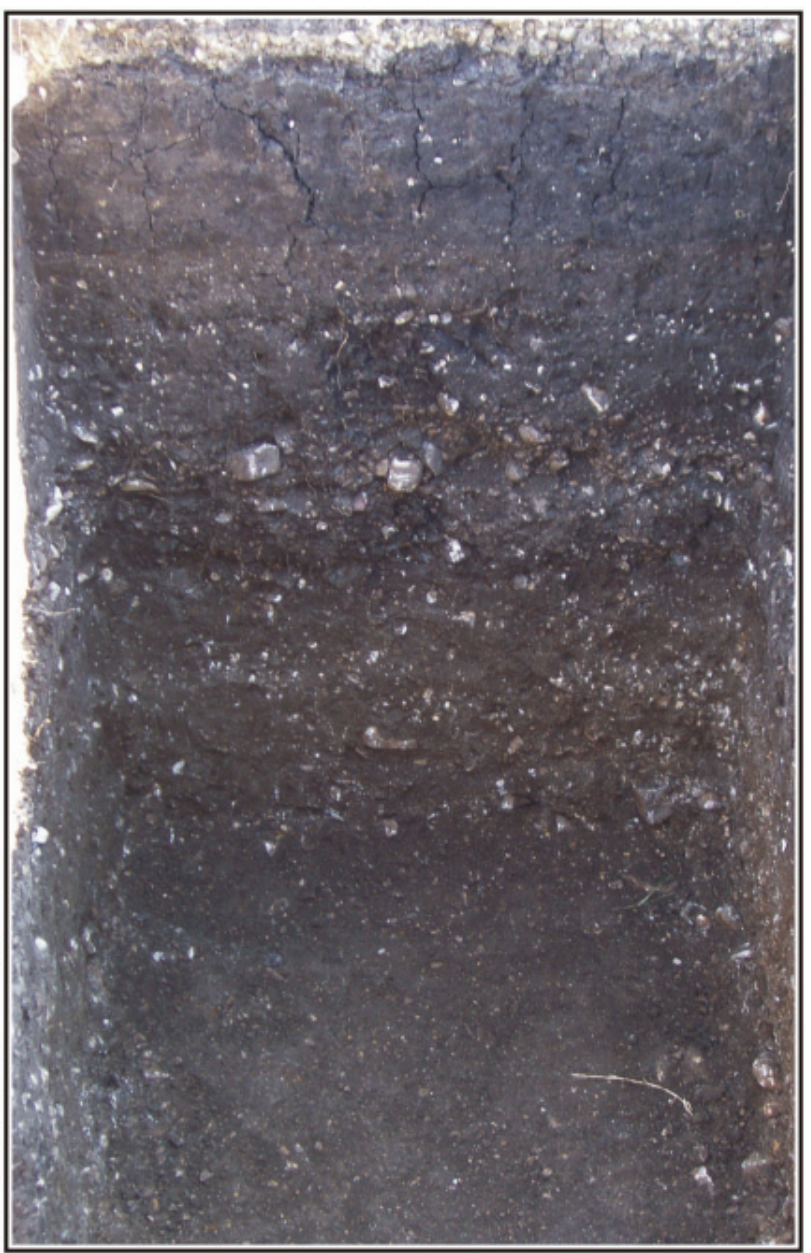

Figure 4-5. South wall profile of Test Unit 1.

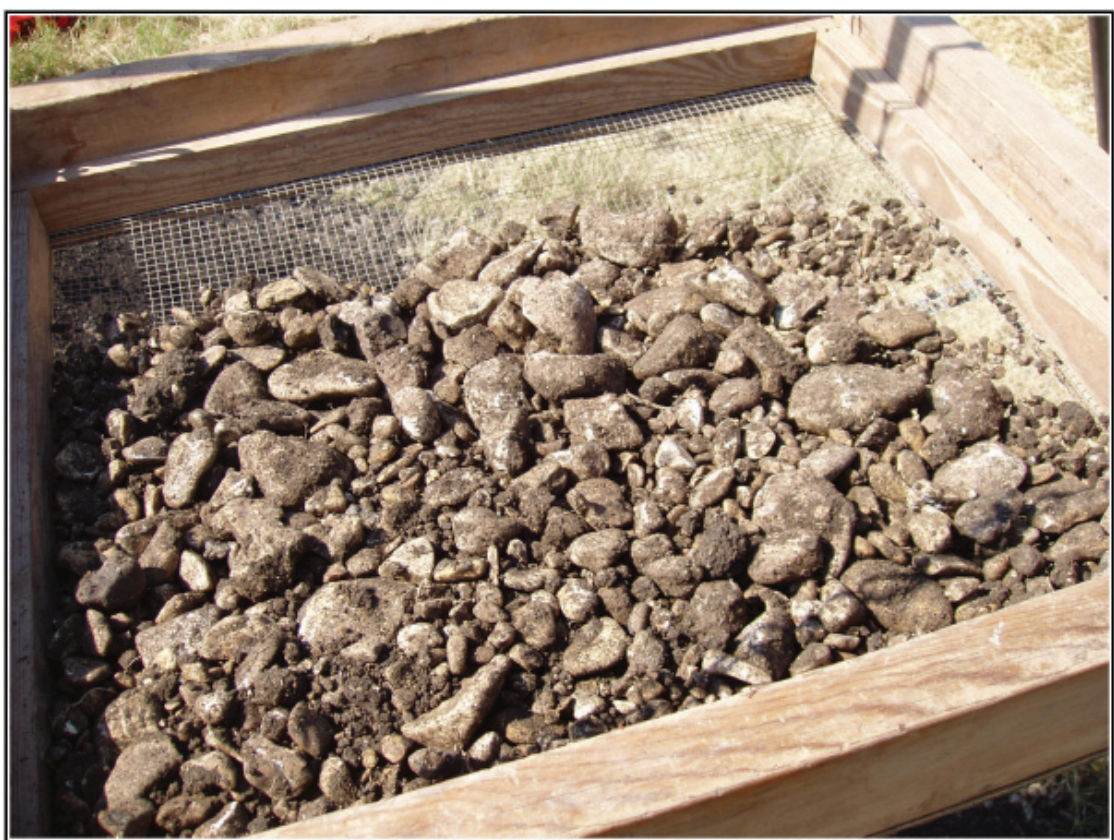

Figure 4-7. Screening heavy gravel layer (Level 7) in Test Unit 1 excavation. component represented in Zone 3 (Level 4) while the prehistoric component is see in lower gravel lenses that represent high energy depositional events. This evidence indicates at least some of the prehistoric materials were transported into the site.

Based on the positive auger tests east of BHT 13, CAR excavated Test Unit 2 between Auger Tests 3 and 4 (see Figure 4-1). The original scope of work proposed that test units be excavated a total of ten levels; however, due to an increase in cultural material seen in Level 10 excavations were continued below the original target depth. This test unit was excavated in fifteen, 10$\mathrm{cm}$ levels to a depth of $150 \mathrm{cmbd}$. The datum string line was set $5-\mathrm{cm}$ above ground surface southwest of the unit (40 
Table 4-2. Cultural Material Recovered from Test Unit 1

\begin{tabular}{|c|c|c|c|c|c|c|c|c|c|}
\hline Level & glass & ceramic & metal & $\begin{array}{c}\text { burned } \\
\text { rock }\end{array}$ & charcoal & debitage & $\begin{array}{c}\text { lithic tools } \\
\text { and cores }\end{array}$ & $\begin{array}{c}\text { mussel } \\
\text { shell }\end{array}$ & $\begin{array}{c}\text { Grand } \\
\text { Total }\end{array}$ \\
\hline 1 & 0 & 0 & 0 & 0 & 0 & 2 & 0 & 0 & 2 \\
\hline 2 & 2 & 0 & 1 & 0 & 0 & 2 & 0 & 0 & 5 \\
\hline 3 & 9 & 0 & 0 & 1 & 0 & 0 & 0 & 0 & 10 \\
\hline 4 & 24 & 16 & 31 & 1 & 1 & 1 & 0 & 1 & 75 \\
\hline 5 & 0 & 0 & 0 & 0 & 0 & 3 & 0 & 0 & 3 \\
\hline 6 & 0 & 0 & 0 & 1 & 0 & 2 & 0 & 0 & 3 \\
\hline 7 & 0 & 0 & 0 & 2 & 0 & 13 & 1 & 0 & 16 \\
\hline 8 & 0 & 0 & 0 & 1 & 0 & 7 & 0 & 0 & 8 \\
\hline 9 & 0 & 0 & 0 & 17 & 0 & 23 & 0 & 0 & 40 \\
\hline 10 & 0 & 0 & 0 & 3 & 0 & 11 & 0 & 1 & 15 \\
\hline 11 & 0 & 0 & 0 & 6 & 0 & 6 & 0 & 0 & 12 \\
\hline 12 & 0 & 0 & 0 & 3 & 0 & 6 & 0 & 0 & 9 \\
\hline 13 & 0 & 0 & 0 & 2 & 0 & 11 & 0 & 0 & 13 \\
\hline Grand Total & 35 & 16 & 32 & 37 & 1 & 87 & 1 & 2 & 211 \\
\hline
\end{tabular}

$\mathrm{cm})$. A total of $1.4 \mathrm{~m}^{3}$ of soil was hand excavated from Test Unit 2.

The east wall profile of the test unit is depicted in Figure 4-8. As seen in Test Unit 1 and auger testing, the upper layers of Test Unit 2 consisted of fill (Zones 1 and 2) ranging from 5 to $30 \%$ gravel. Zone 3 may represent the same Zone 3 strata in Test Unit 1. Zone 4 of the test unit is a heavy gravel lens. Zone 5, an intact deposit of clay, underlies the gravel lens. Prehistoric artifact densities escalated in this stratum (Levels 10-12; Table 4-3), prompting additional levels to be excavated. The remainder of the test unit (Levels 13-15) consisted of two gravel lenses.

Levels 1 through 3 represented mixed deposits containing lithic debitage and glass. Few pieces of lithic debitage and burned rock were recovered from Levels 4 through 9. Levels 9 through 12 consisted of a clay matrix (see Figure 4-8, Zone 5). Two large pieces of burned rock (Figure 4-9) were found at 100 to $104 \mathrm{cmbd}$ (Level 11) although no charcoal or staining were associated with them. In addition, fifty-four pieces of lithic debitage, seventeen pieces of burned rock and one core also were recovered from this level. Level 12 also contained high densities of burned rock $(\mathrm{n}=24)$ and lithic debitage ( $\mathrm{n}=60)$, along with a core. The majority of artifacts recovered from Test Unit 2 consisted of lithic debitage and burned rock and was concentrated in Levels 11 and 12. The deposit seen in Levels 11 and 12 was above a gravel lens (Levels 13 through 15) that contained little cultural material (Figure 4-10).

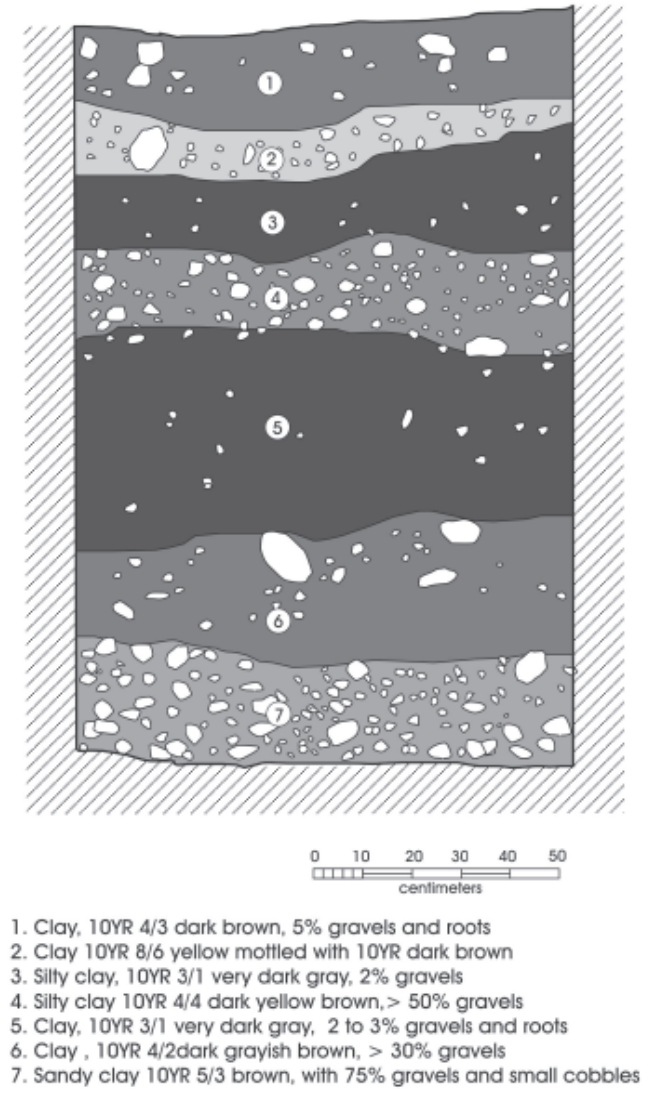

Figure 4-8. East wall profile of Test Unit 2. 
Table 4-3. Cultural Material Recovered from Test Unit 2

\begin{tabular}{|c|c|c|c|c|c|}
\hline Level & $\begin{array}{c}\text { burned } \\
\text { rock }\end{array}$ & debitage & glass & $\begin{array}{c}\text { lithic tools } \\
\text { and cores }\end{array}$ & $\begin{array}{c}\text { Grand } \\
\text { Total }\end{array}$ \\
\hline 2 & 0 & 3 & 1 & 0 & 4 \\
\hline 3 & 1 & 0 & 2 & 0 & 3 \\
\hline 4 & 0 & 2 & 0 & 0 & 2 \\
\hline 6 & 0 & 5 & 0 & 0 & 5 \\
\hline 7 & 0 & 2 & 0 & 1 & 3 \\
\hline 8 & 0 & 11 & 0 & 1 & 12 \\
\hline 9 & 4 & 12 & 0 & 0 & 16 \\
\hline 10 & 5 & 17 & 0 & 0 & 22 \\
\hline 11 & 19 & 54 & 0 & 1 & 74 \\
\hline 12 & 24 & 60 & 0 & 1 & 85 \\
\hline 13 & 1 & 7 & 0 & 0 & 8 \\
\hline 14 & 0 & 3 & 0 & 0 & 3 \\
\hline 15 & 0 & 3 & 0 & 1 & 4 \\
\hline $\begin{array}{c}\text { Grand } \\
\text { Total }\end{array}$ & 54 & 179 & 3 & 5 & 241 \\
\hline
\end{tabular}

In order to further explore the intact deposit seen in Test Unit 2, Backhoe Trench 1 was excavated perpendicular to the Hwy 90 access road near Auger Test 1 (see Figure 4-1). A thin layer of clay matrix was found at $145 \mathrm{cmbs}$ (similar to Zone 5 in Test Unit 2), situated between gravel lenses (the first lens encountered at $110 \mathrm{cmbs}$; Figure 4-11). Test Unit 3 was placed on the eastern wall of the backhoe trench, after the eastern wall had been scraped to $110 \mathrm{cmbs}$. The datum was

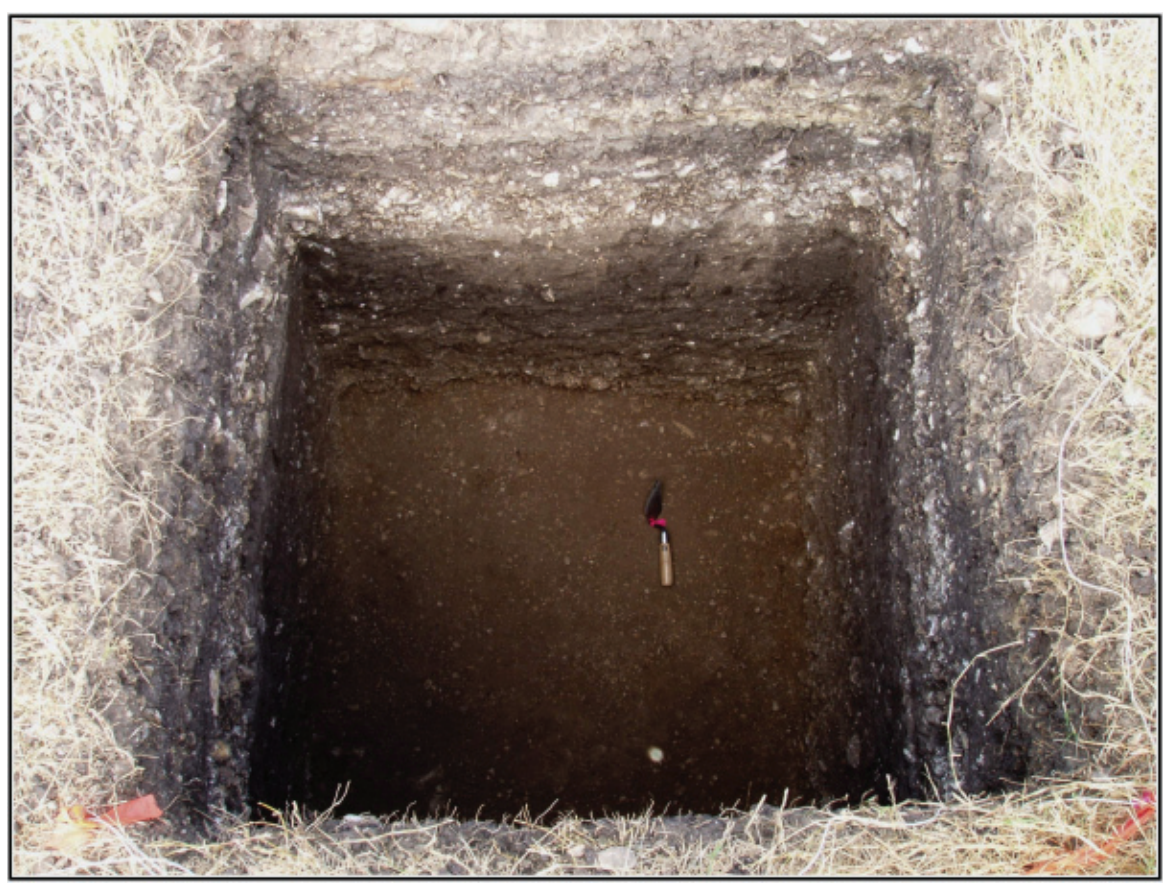

Figure 4-10. Test Unit 2 at terminal depth of $150 \mathrm{cmbd}$.

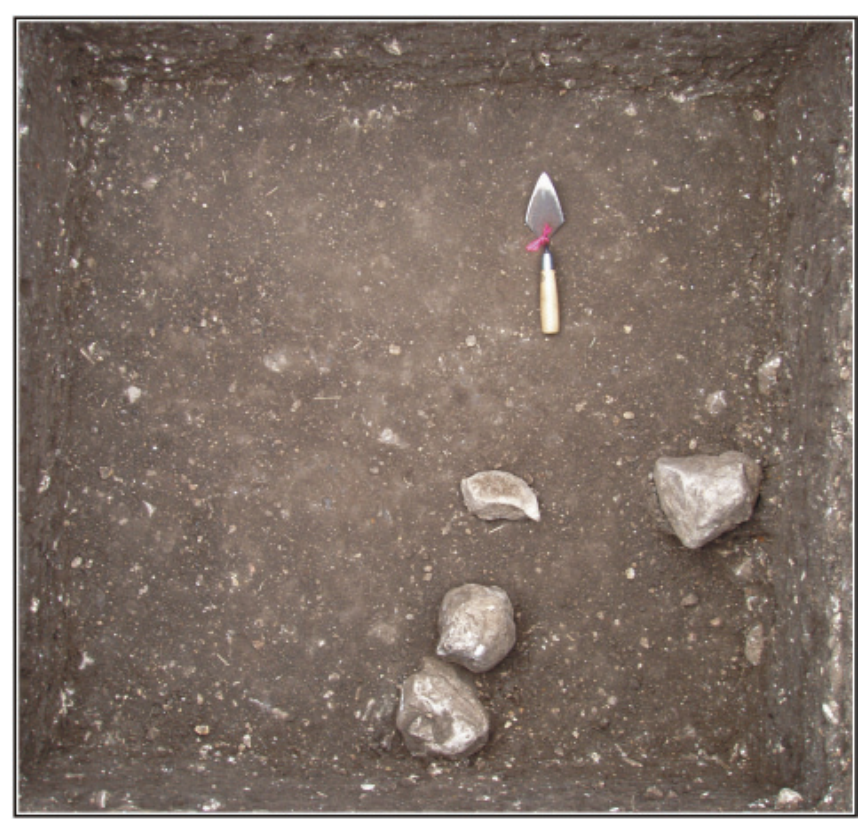

Figure 4-9. Intact deposits (at $110 \mathrm{cmbd}$ ) in Test Unit 2, note FCR and unmodified cobbles.

set $95 \mathrm{~cm}$ below ground surface in the southwest corner of the test unit. Level 1 started at $23 \mathrm{cmbd}(118 \mathrm{cmbs})$. The amount of soil removed by hand excavations totaled $0.36 \mathrm{~m}^{3}$. The test unit was excavated in four $10-\mathrm{cm}$ levels and terminated at $60 \mathrm{cmbd}(155 \mathrm{cmbs})$. Zone 1 contained $>40 \%$ gravel (Levels 1 through 2) and contained lithic debitage $(\mathrm{n}=1)$ and burned rock $(\mathrm{n}=4)$. The clay matrix in Levels 3 and 4 likely represent the intact deposit seen in Test Unit 2, though it is much thinner in this unit and deeper in elevation. Although the amounts of lithic debitage $(n=24)$ and burned rock $(n=9)$ are greater than in Levels 1 and 2 (Table 4-4), they are dramatically less than artifacts observed in Test Unit 2 (Levels 10-12). The prehistoric deposit seen in Test Unit 2 (Levels 10-12) produced 603 artifacts per $\mathrm{m}^{3}$, while presumably the same component in Test Unit 3 produced less $\left(160\right.$ artifacts per $\left.\mathrm{m}^{3}\right)$.

\section{Summary}

CAR conducted mechanical auger tests, 1-x-1 meter test unit excavations, and backhoe trenching as a part of NRHP eligibility testing of site 41BX1749 during October and November of 2007. Auger tests helped establish that the upper portion of the site was covered with gravel fill. Moreover, auger tests 
Table 4-4. Cultural Material Recovered from Test Unit 3

\begin{tabular}{|l|c|c|c|}
\hline \multicolumn{1}{|c|}{ Level } & burned rock & debitage & $\begin{array}{c}\text { Grand } \\
\text { Total }\end{array}$ \\
\hline $1(1.8-1.28 \mathrm{bs})$ & 0 & 1 & 1 \\
\hline $2(1.28-1.38 \mathrm{bs})$ & 4 & 0 & 4 \\
\hline $3(1.38-1.47 \mathrm{bs})$ & 8 & 7 & 15 \\
\hline $4(1.47-1.55 \mathrm{bs})$ & 1 & 17 & 18 \\
\hline Grand Total & 13 & 25 & 38 \\
\hline
\end{tabular}

revealed that the western reaches of the site were disturbed further by utilities. The eastern portion of the site proved to be less disturbed and contained the majority of prehistoric artifacts.

The excavation of three 1-x-1 meter test units followed the mechanical auger testing. Test Unit 1 was excavated adjoining the south wall of the reopened BHT 13. This test unit revealed a historical component that produced glass and a variety of late 19 th to early 20 th century ceramics, primarily confined to Test Unit 1. Prehistoric materials were recovered from a series of gravel lenses. Test Unit 2 was located between Auger Tests 3 and 4. This test unit produced little historical material but a high density of lithic debitage and burned rock was recovered from an intact clay deposit (at $100 \mathrm{cmbs}$ ).

The findings in Test Unit 2 prompted the excavation of BHT 1 on the eastern portion of the site. The backhoe trench was excavated to determine if intact deposits continued to the east. A thin clay deposit was encountered during the excavation of BHT 1 at $145 \mathrm{cmbs}$, situated between two gravel layers (as seen in Test Unit 2). Test Unit 3 was excavated after the eastern wall of BHT 1 was scraped down above the clay

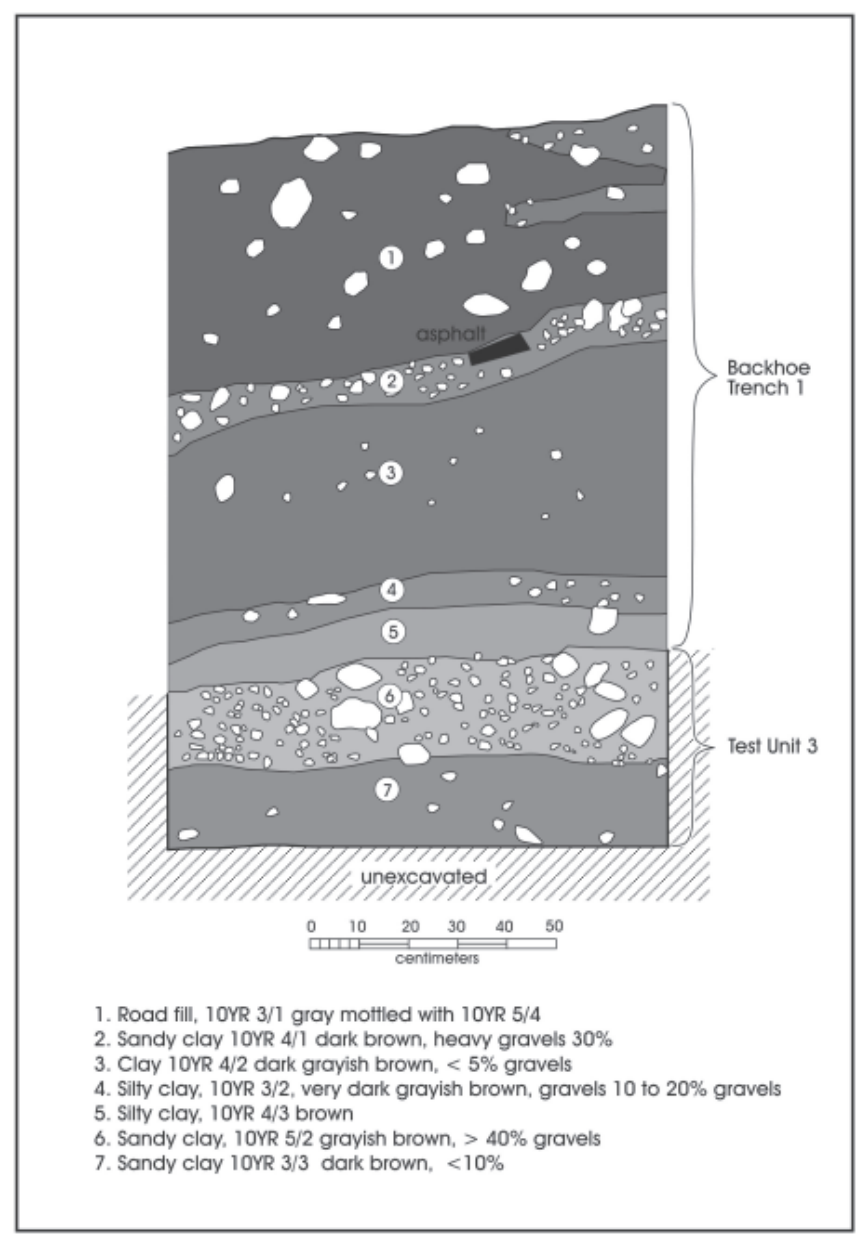

Figure 4-11. East wall profile of Test Unit 3 and Backhoe Trench 1.

lens. Although prehistoric material was recovered from this deposit, the densities were lower than artifact recovery from Test Unit 2. 



\section{Chapter 5: Cultural Material}

Test unit excavations at 41BX1749 produced 489 artifacts consisting of historical and prehistoric materials. This section of this chapter presents a short summary of archival research on the historic component at the site. This is followed by an examination of the prehistoric materials recovered from the test unit excavations. The prehistoric material consisted of lithic debitage $(\mathrm{n}=291)$, burned rock $(\mathrm{n}=104)$, and lithic tools and cores $(\mathrm{n}=6)$. All of the prehistoric lithic material was chert.

\section{Archival Research}

The historical artifacts recovered from the site, described in the previous chapter, consisted of late 19th to early 20th century ceramics, unidentified metal and glass, as well as cut nails. In an effort to shed light on the context of these historical materials, which were primarily recovered from Test Unit 1, we initially consulted several topographic maps stored at the CAR laboratory. The earliest map depicting the project area is a General Land Office map (TNRIS 2008) and shows the land as originally granted to C. Texanda (Tejada). The 1903 U.S. Geological Survey map (U.S. Dept. of Interior) illustrates that the $19^{\text {th }}$ century road to Castorville (currently overlain by US 90) runs adjacent to the project area. In addition, the map identifies a structure within the project area, although no architectural details are depicted. The structure is no longer present on a 1942 map drawn by the Corps of Engineers that shows the project area. The artifacts found in the project area could have originated from the structure depicted in the 1903 map.

A deed search of the property was conducted starting with the property that abuts the project area to the north. The property immediately north of the existing ROW belongs to a Hugo Stolte Jr. The land was granted to Hugo Stolte Jr. in 1975 by Louis A. Kriewald and Jessie V. Kriewald (BCHR Vol. 3798:844). The deed states the land is out of the Clemente Texada Survey 69. In 1944 the land was conveyed to the children of Louis and Emma Kriewald in the form of a warranty deed of gift (BCHR Vol. 2019:543). Louis Kriewald Jr. was one of these children. According to the deed records, W. T. Hodges conveyed the land to L. Kriewald in 1907 (BCHR Vol. 280:81). Between 1907 and 1975 there is no mention of a structure in the deed records. Each time the land is described as being a part of the Clemente Texada land grant on Medio Creek.

In 1904 the land was conveyed to W. T. Hodges by A. J. Schultze (BCHR Vol. 226:408). The earliest deed consulted was dated 1893 and the property was granted to A. J. Schultze by P. C. Talyor (BCHR Vol. 119:76). An agreement of partition, dated 1880 (BCHR Vol. 16:264), between P.C. Taylor and W.T. Bowen shows the plat. It seems plausible that the structure depicted on the 1903 map was probably constructed when the property was in the hands of A.J. Schultze or P.C. Taylor.

\section{Lithic Debitage}

Unmodified lithic debitage $(\mathrm{n}=291)$ was recovered from all three test units excavated at 41BX1749. The majority of the debitage $(62 \% ; n=179)$ came from Test Unit 2. Although Test Unit 2 contained most of the debitage, the majority was recovered from Levels 11 and $12(\mathrm{n}=131 ; 73 \%)$. Test Unit 1 produced $30 \%$ of the debitage and Test Unit 3 only $8 \%$. An analysis of the debitage was conducted recording the following attributes: maximum dimension $(\mathrm{mm})$, cortex $\%$, patina, flake completeness and the number of platform facets.

Many of the recorded attributes are diagnostic of reduction processes. For instance, specimens that are smaller and exhibit less cortex are thought to derive from the late reduction stage. The smaller the piece of debitage, the closer to completion the end product is assumed to be. The average maximum dimension of the debitage measured $21.6 \mathrm{~mm}$. In Test Unit 1, the average dimension of debitage was $21.1 \mathrm{~mm}$, in Test Unit 2 it was $21.5 \mathrm{~mm}$ and in Test Unit 3 it was $23.2 \mathrm{~mm}$. Debitage specimens from the intact deposit (Zone 5) found in Test Unit 2 (Levels 10-12) measured $20.4 \mathrm{~mm}$.

The cortex percentage categories used when examining this assemblage were $0 \%$ (tertiary), $1-50 \%$ (secondary) and 51 $100 \%$ (primary). The majority of specimens, $76 \%$, had no cortex, followed by secondary flakes $(15 \%)$ and primary flakes $(9 \%)$. This pattern was consistent across the individual test units.

The presence of patina on lithic material has been used to infer age since typically patina is correlated with older materials. It is evident at some sites that the occurrence of patinated material increases with depth (Frederick et al. 1994; Bement 1989). Sixty-six percent of the specimens from Test Unit 1 and 2 are patinated. A chi-square test indicates with greater than $99.9 \%$ confidence that patinated specimens occur more often at lower levels (Chi-Square $=44.93, \mathrm{p}=.000, \mathrm{df}=13$ ). 
The completeness of all specimens was also recorded. The percentage of complete flakes versus medial/distal and proximal fragments has been used by researchers to determine if assemblages are a result of tool or core reduction activities (Sullivan and Rozen 1985). The majority of specimens (all test units), 57\%, was comprised of medial/distal flakes. Out of the assemblage, $31 \%$ were complete flakes and $12 \%$ were proximal flakes. Angular debris was absent from this assemblage. The debitage from the intact deposit (Levels 10-12 in Test Unit 2) mimicked a similar pattern of flake completeness with $61 \%$ medial/distal flakes, $28 \%$ complete and $12 \%$ proximal. These percentages are similar to Sullivan and Rozen's (1985) percentages from tool reduction assemblages. Breakage patterns could also be a result of raw material types (Amick and Mauldin 1997) and taphonomic processes (Prentiss and Romanski 1989).

It has been suggested that the number of facets on the platform is telling of reduction and whether core reduction or tool reduction was occurring at a site (Andrefsky 1998, Tomka 1989, 2001). Single facet platforms are indicative of core reduction while, tool reduction should result in multiple-faceted flakes. This attribute could only be recorded on complete and proximal specimens $(\mathrm{n}=125)$. The majority of complete and proximal flakes from Test Units 1, 2 and 3 possessed single platform facets $(62.4 \%)$, while $30.4 \%$ had three or more facets. Only $7.2 \%$ of complete and proximal flakes had two platform facets. The assemblage of complete and proximal flakes from Levels 10-12 in Test Unit 2 has a similar pattern with $58.8 \%$ single platform facets, $5.9 \%$ with two platform facets and $35.3 \%$ of three or more platform facets.

\section{Lithic Tools and Cores}

Three cores and three retouched flakes were recovered from test unit excavations (Figure 5-1). All three cores are made of chert and were from Test Unit 2, Levels 7, 8 and 12 . Three measurements were taken on each core specimen, length, width and thickness. The largest of the three cores, a unidirectional core, was from Level 12. It measured $64 \times 61 \times 53$ mm with $26-50 \%$ cortex. The other two cores were smaller and are exhausted. The core from Level 7 measures $41 \times 32 \times 11.5 \mathrm{~mm}$, while the core from Level 8 is $45 \times 36 \times 22 \mathrm{~mm}$.

Three informal flake tools were also recovered from test unit excavations. The flake tool retrieved from Test Unit 1 is retouched on the dorsal face. The tool is a complete flake with $0 \%$ cortex and a width/thickness ratio of 3.4. Two retouched flakes were from Test Unit 2. The first retouched flake (from Level 11 ) is made of a complete flake, possessing $1-25 \%$ cortex. It is retouched on its dorsal face and has a width/thickness ratio of 3.7. The second retouched flake recovered from Test Unit 2 (Level 15) is also a complete flake. It has been retouched on the dorsal face, with $76-100 \%$ cortex.

\section{Summary}

Historic materials, recovered primarily from Test Unit 1 at 41BX1749, included cut nails, glass, unidentified metal, and late 19th century to early 20 th century ceramics. This material may be associated with a structure, of unknown function, which was present in the project area in 1903. Most of prehistoric material (73\%) consisted of unmodified lithic debitage. The results of the debitage analysis show that the average size of the debitage is $21.6 \mathrm{~mm}$ and specimens from Test Unit 2 measure only a bit smaller at $20.4 \mathrm{~mm}$. The majority of specimens, from the entire assemblage, did not exhibit cortex. Patinated material was encountered more often in deeper levels. When comparing debitage completeness and platform facets the data are conflicting. However, the high percentage of medial/distal flakes could be a result of post depositional activities. The platform bearing flakes exhibited mostly single facet platforms that could be a result of core reduction activities. The patterns seen in the overall assemblage was mimicked in the specimens from the intact soil horizon observed in Test Unit 2 (Levels 10-12). Moreover, the lack of formal tools confirms core reduction activities. Additional investigations of the intact prehistoric deposit encountered at 41BX1749 could shed light on such issues.

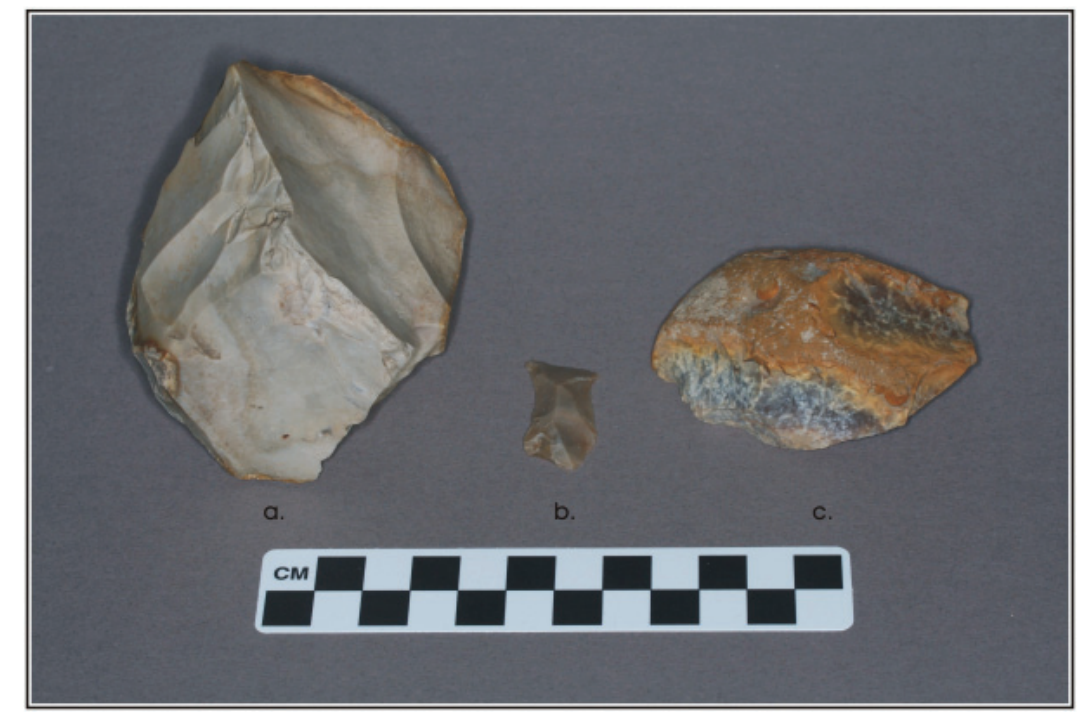

Figure 5-1. Lithic core ( $A)$ and retouched flake ( $B$ and $C$ ) tools recovered from test unit excavations. 


\section{Chapter 6: Conclusions and Recommendations}

CAR conducted NRHP eligibility testing at site 41BX1749 in October and November of 2007. 41BX1749 was originally recorded by CAR in 2007 during the survey phase of the Loop 410 Improvements Project (Figure 6-1). The site is located in the immediate environs of Medio Creek in southwest Bexar County. The size of the site within the ROW is $2237 \mathrm{~m}^{2}$ being bound to the north by a fence line and to the south by the Loop 410 access road. Medio Creek bounds the site to the west, while BHT 1 defines the eastern boundary. Archeological methods implemented during the testing of the site included mechanical auger tests, 1-x-1 meter test excavations and backhoe trenching. Results from testing indicated the upper portion of the site was covered with gravel fill and western reaches of the site had been disturbed by utility installations.

Test unit excavations revealed the site had a historical and prehistoric component. The historical component was quite evident in Test Unit 1 with the recovery of cut nails, glass, unidentified metal, and late $19^{\text {th }}$ to early $20^{\text {th }}$ century ceramics. This material may be associated with a structure, of unknown function, which was present in the project area in 1903. The structure was destroyed sometime before 1942. A deed search of the location suggests that the structure depicted on the 1903 USGS map was probably constructed when the property was in the hands of an A.J. Schultze or P.C. Taylor. No additional information regarding the structure or the property could be located.

The prehistoric materials from Test Unit 1 were situated within a series of gravel lenses. Test Unit 2 produced little historical material but a high density of debitage and burned rock was found within a clay deposit at $100 \mathrm{cmbs}$. This deposit was sandwiched between two gravel lenses. Although no features or datable materials were recovered from the deposit, burned rock was common. CAR believes the deposit accumulated on a stable occupation surface.

One of the final tasks of testing at the site included the excavation of BHT 1 and Test Unit 3. BHT 1 was placed near negative Auger Test 1 to determine if the intact deposit encountered in Test Unit 2 was present in this portion of the site. A thin clay deposit was encountered in BHT 1 at 145 $\mathrm{cmbs}$ and situated between two gravel lenses. Test Unit 3 was excavated to explore the clay deposit. Although prehistoric material was recovered from the deposit, artifact densities were much lower than densities observed in Test Unit 2. Based on the findings in Test Unit 2, the prehistoric component of the site is intact and further exploration is recommended between Test Unit 2 and Test Unit 1. Furthermore, we recommend that the site is eligible for listing in the NRHP under criterion D in that the intact prehistoric component of the site could yield information important to Texas prehistory. No additional investigation is recommended for the historic component at the site.

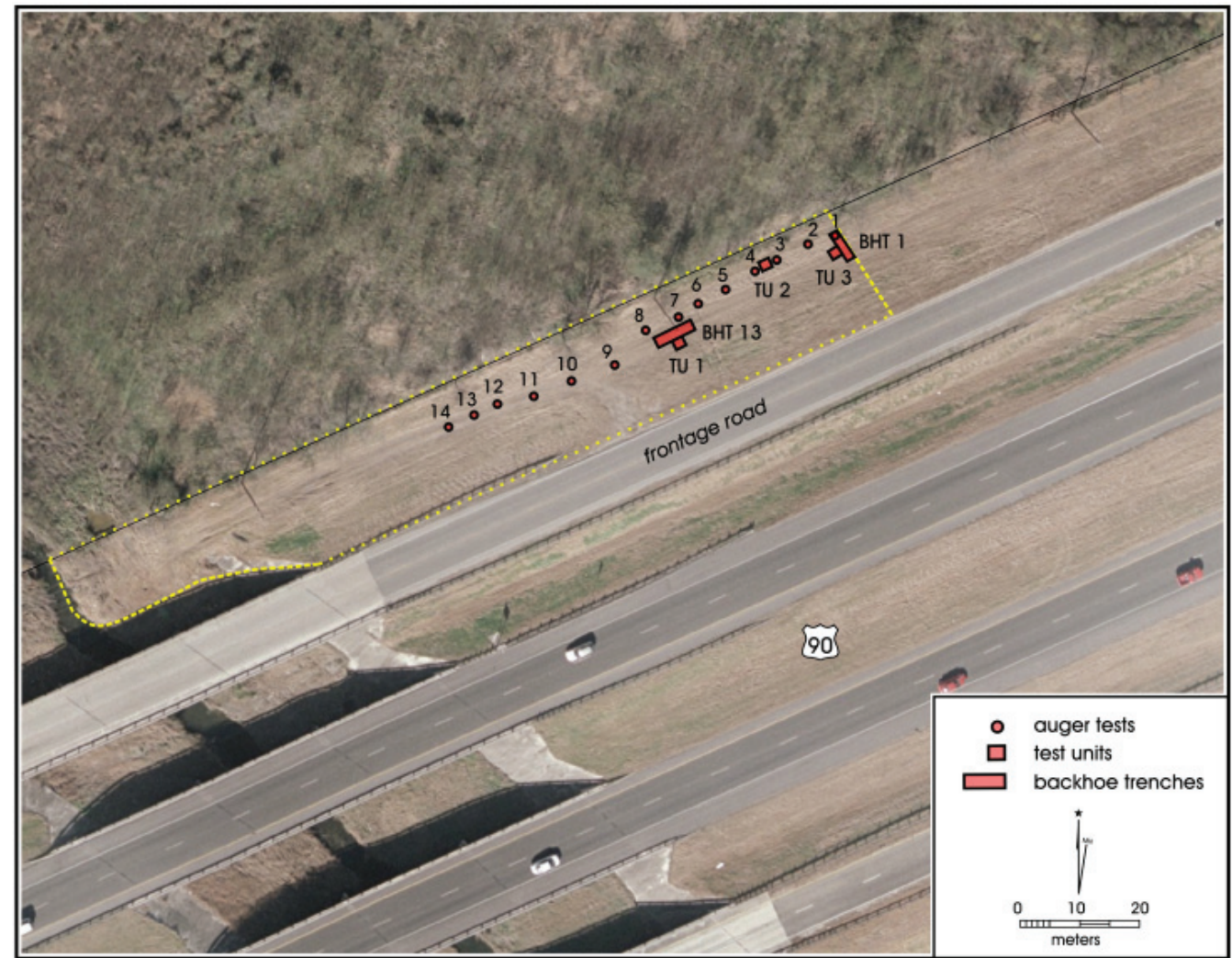

Figure 6-1. $41 B X 1749$ site boundary. 



\section{References Cited}

Amick, D. and R.P. Amick

1997 Effects of Raw Material on Flake Breakage Patterns. Lithic Technology 22 (1):18-32.

Andrefsky, W. Jr.

1998 Lithics: Macroscopic Approaches to Analysis. University Press, Cambridge.

Bement, L.C.

1989 Excavations at 41BP19: The Kennedy Bluffs Site, Bastrop County, Texas. Texas Archeological Research Laboratory, The University of Texas at Austin. Contract Reports in Archeology, Report No. 5, Highway Design Division, Texas State Department of Highways and Public Transportation, Austin.

Berlandier, J.L.

1980 Journey to Mexico during the years 1826-to 1834. translated by S.M. Ohlendorf. Texas State Historical Association, University of Texas, Austin.

Bexar County Historical Records

2008 http://www.countyclerk.bexar.landata.com/, Accessed January 24, 2008.

Black, S.L.

1989a Central Texas Plateau Prairie. In From the Gulf Coast to the Rio Grande: Human Adaptation in the Central, South, and Lower Pecos Texas, by T. R. Hester, S. L. Black, D. G. Steele, B. W. Olive, A. A. Fox, K. J. Reinhard, and L. C. Bement, pp. 17-38. Research Series No. 33. Arkansas Archaeological Survey, Fayetteville.

1989b South Texas Plain. In From the Gulf Coast to the Rio Grande: Human Adaptation in the Central, South, and Lower Pecos Texas, by T. R. Hester, S. L. Black, D. G. Steele, B. W. Olive, A. A. Fox, K. J. Reinhard, and L. C. Bement, pp. 39-62. Research Series No. 33. Arkansas Archaeological Survey, Fayetteville.

Black, S. L., and A. J. McGraw

1985 The Panther Springs Creek Site: Cultural Change and Continuity in the Upper Salado Creek Drainage, South-Central Texas. Archaeological Survey Report, No. 100. Center for Archaeological Research, The University of Texas at San Antonio.

Bomar, G. W.

1983 Texas Weather. University of Texas Press, Austin.

2001 San Antonio Springs. The Handbook of Texas Online. http://www.tsha.utexas.edu/handbook/online/articles/SS/rps4. html, Accessed November 20, 2008

Bousman, C. B.

1998 Paleoenvironmental Change in Central Texas: The Palynological Evidence. Plains Anthropologist (43)164:201-219.

Brune, G.

2001 San Antonio Springs. The Handbook of Texas Online. http://www.tsha.utexas.edu/handbook/online/articles/SS/rps4. html. Accessed November 20, 2007. 
Bryant, V. M., Jr., and H. J. Shafer

1977 The Late Quaternary Paleoenvironment of Texas: A Model for the Archeologist. Bulletin of the Texas Archeological Society 48:1-25.

Chipman, D. E.

2001 The Espinosa-Olivares-Aguirre Expedition. The Handbook of Texas Online. http://www.tsha.utexas.edu/handbook/ online/articles/EE/upe1.html. Accessed July 16, 2007.

Cleveland, A.G., and D.D. McCain

1992 Habitat Study of the Lackland Air Force Base Medina Annex Flora and Fauna. Report submitted to the U.S. Air Force, Contract No. F4163691PF453. Lackland Air Force Base, San Antonio.

Collins, M. B.

1995 Forty Years of Archeology in Texas. Bulletin of the Texas Archeological Society 66:361-400.

Collins, M., D. Hudler and S. L. Black

2003 Pavo Real (41BX52): A Paleoindain and Archaic Camp and Workshop on the Balcones Escarpment, South-Central Texas. Studies in Archeology 41. Texas Archeological Research Laboratory.

De Vore, S. L.

1993 Cultural Resource Assessment of Lackland Air Force Base and Training Annex, Bexar Country, Texas. U.S. Department of the Interior, National Park Service, Rocky Mountain Regional Office, Denver.

Fehrenbach, T. R.

2004 San Antonio, Texas. The Handbook of Texas Online. http://www.tsha.utexas.edu/handbook/online/articles/SS/hds2. html. Accessed July 16, 2007.

Forrestal, P. P.

1935 Pena's Diary of the Aguayo Expedition. Preliminary Studies of the Texas Catholic Historical Society 2(7).

Frederick, C.D.

Evaluation of Chert Patination as a Dating Technique: A Case Study from Fort Hood, Texas. Mariah Associates, Austin. Research Report No. 32. Archaeological Resource Management Series, United States Army, Fort Hood.

Gould, F. W.

1975 Texas Plants: A Checklist and Ecological Summary. Bulletin MP-585:5-14. Texas Agricultural Experimentation Station, College Station.

Greaves, R. D., R. P. Mauldin, and S. A. Tomka

2002 An Archaeological Survey of Trail Locations in a Portion of Government Canyon State Natural Area, Bexar County, Texas. Volume 1: Project Summary, Survey Results, and Recommendations. Archaeological Survey Report, No. 329. Center for Archaeological Research, The University of Texas at San Antonio, San Antonio.

Hatcher, M. A.

1932 Expedition of Don Domingo Teran de Los Rios into Texas. Preliminary Studies of the Texas Catholic Historical Society 2(1). 
Hester, T.R.

1979 Early Populations in Prehistoric Texas. Archaeology 32(6):26-33.

1990 Plainview Artifacts at the St. Mary's Hall Site, South Central Texas. Current Research in the Pleistocene 7:14-17.

1995 The Prehistory of South Texas. Bulletin of the Texas Archaeological Society 66: 427-459.

Houk, B.A., and D.L. Nickels

1997 Phase II Archaeological Investigations at Lackland Air Force Base, San Antonio, Texas. Archaeological Survey Report, No. 264. Center for Archaeological Research, The University of Texas at San Antonio.

McGraw, J.A., J.W. Clark, Jr., and E.A. Robbins

1998 A Texas Legacy the Old San Antonio Road and the Caminos Reales: A Tricentennial History, 1691-1991. Texas Department of Transportation, Environmental Affairs Division, Austin.

Meissner, B.A., K.J. Córdova and A.L. Figueroa

n.d. Archaeological Survey of the Loop 410 Improvements Project, Bexar County, Texas. Center for Archaeological Research, The University of Texas at San Antonio.

Nickels, D.L., D.W. Pease, and C.B. Bousman

1997 Archaeological Survey of Lackland Air Force Base, Bexar County, Texas. Archaeological Survey Report, No. 248. Center for Archaeological Research, The University of Texas at San Antonio.

Nickels, D. L., and R. P. Mauldin

2001 An Archaeological Survey of Twin Buttes Reservoir, Tom Green County, Texas, Volume 1. Archaeological Survey Report, No. 300, Center for Archaeological Research, The University of Texas at San Antonio.

Potter, D. R., S. L. Black, and K. Jolly (editors)

1995 Archeology Along the Wurzbach Parkway: Module 1 Introduction, Conceptual Framework, and Contexts of Archeological Investigations in Bexar County, South-Central Texas. Studies in Archeology, No. 18, Texas Archeological Research Laboratory, The University of Texas at Austin.

Prentiss, W.C. and E.J. Romanski

1989 Experimental Evaluation of Sullivan and Rozen's Debitage Typology. In Experiments in Lithic Technology, edited by D.S. Amick and R.P. Mauldin, pp. 89-99. British Archaeological Reports International Series 528, Oxford.

Skelton, D. W.

1977 Archeological Investigations at the Fayette Power Project, Fayette County, Texas. Research Report 60. Texas Archeological Survey, The University of Texas at Austin.

Sullivan, A. P., III and K. Rozen

1985 Debitage Analysis and Archaeological Intrepretation. American Antiquity 50(4):755-779.

Taylor, F. B., R. B. Hailey, and D. L. Richmond

1991 Soil Survey of Bexar County, Texas. U.S. Department of Agriculture Soil Conservation Service. Washington, D.C.: The Soil Conservation Service. 
Texas Natural Resource Information System (TNRIS)

2008 http://www.tnris.sta 'te.tx.us/datadownload/county.jsp?Name=BEXAR, Accessed January 24, 2008.

Texas Historical Commission (THC)

2007 Texas Archeological Sites Atlas, http://www.nueces.thc.state.tx.us, accessed July, 2008.

Tomka, S. A.

1989 Differentiating Lithic Reduction Techniques: An Experimental Approach. In Experiments in Lithic Technology, edited by D. S. Amick and R. P. Mauldin, pp. 137-161. British Archaeological Reports International Series 528, Oxford.

2001 Chapter 10: Lithic Artifacts. In Archaeological Investigations at a Spanish Colonial Site, (41KA26-B), Karnes County, Texas. edited by C. L. Tennis, pp. 65-71. Archaeological Research Report, No. 302. Center for Archaeological Research, The University of Texas at San Antonio.

Turner, S. E., and T. R. Hester

1993 A Field Guide to Stone Artifacts of Texas Indians. Gulf Publishing Co., Houston.

Weir, F. A.

1976 The Central Texas Archaic. Unpublished Ph.D. dissertation, Department of Anthropology, Washington State University.

Weniger, D.

1997 The Explorers' Texas. Volume 2: The Animals They Found. Eakin Press, Austin. 